NBER WORKING PAPER SERIES

\title{
QUANTIFYING THE BENEFITS OF SOCIAL INSURANCE: UNEMPLOYMENT INSURANCE AND HEALTH
}

\author{
Elira Kuka \\ Working Paper 24766 \\ http://www.nber.org/papers/w24766 \\ NATIONAL BUREAU OF ECONOMIC RESEARCH \\ 1050 Massachusetts Avenue \\ Cambridge, MA 02138 \\ June 2018
}

I am grateful to Marianne Bitler, Scott Carrell, Brian Duncan, Hilary Hoynes, Doug Miller, Dann Mil-limet, Rafael Lalive, Chris O'Leary, Marianne Page, Na'ama Shenhav, Ann Stevens, and seminar participants UC Davis, the WEAI Graduate Student Dissertation Workshop, and Dartmouth College for excellent com- ments and suggestions. I also thank Brian Melzer for providing UI benefits data, Raj Chetty for making available his UI calculator, and Hilary Hoynes for providing the original Gruber (1997) calculator. The views expressed herein are those of the author and do not necessarily reflect the views of the National Bureau of Economic Research.

NBER working papers are circulated for discussion and comment purposes. They have not been peer-reviewed or been subject to the review by the NBER Board of Directors that accompanies official NBER publications.

(C) 2018 by Elira Kuka. All rights reserved. Short sections of text, not to exceed two paragraphs, may be quoted without explicit permission provided that full credit, including (C notice, is given to the source. 
Quantifying the Benefits of Social Insurance: Unemployment Insurance and Health

Elira Kuka

NBER Working Paper No. 24766

June 2018

JEL No. H5,I1

\title{
$\underline{\text { ABSTRACT }}$
}

While the Unemployment Insurance (UI) program is one of the largest safety net program in the U.S., research on its benefits is limited. This paper exploits plausibly exogenous changes in state UI laws to empirically estimate whether UI generosity mitigates any of the previously documented negative health effects of job loss. The results show higher UI generosity increases health insurance coverage and utilization, and leads to improved self-reported health. Moreover, these effects are stronger during periods of high unemployment rates. Finally, I find no effects on risky behaviors nor on health conditions.

\author{
Elira Kuka \\ Department of Economics \\ Southern Methodist University \\ 3300 Dyer Street, Umphrey Lee Center \\ Dallas, TX 75275 \\ and NBER \\ ekuka@smu.edu
}




\section{Introduction}

The Great Recession was one of the deepest and longest recessions in the post World War II period. The unemployment rate increased from 4.6 to 9.6 percent between 2007 and 2010, and the average duration of unemployment increased from 17 to 40 weeks (U.S. Bureau of Labor Statistics). In response to the crisis, the U.S. Congress authorized unprecedented expansions to the Unemployment Insurance (UI) program, lengthening the maximum duration of benefits from 26 to as high as 99 weeks (Rothstein, 2011). As a result of both the depth of the recession and the expansion of the program, UI spending increased substantially, making it the largest U.S. safety net program during this period (Bitler and Hoynes, 2016).

The significant increase in the size of the UI program, coupled with the slow recovery of the labor market after the recession, has spurred renewed interest in estimating the effects of UI on job search and exit from unemployment, and how these affect the optimal level of UI payments. ${ }^{1}$ Because the theory of optimal UI insurance (Baily, 1978; Chetty, 2006) holds that benefit amounts should be set at a level where the costs of the program (the moral hazard effects) should equal its benefits (reduced income fluctuations), the size of this moral hazard is key in calculating the optimal level of UI. On the other hand, understanding and estimating the benefits of UI is equally important, but the literature on these benefits is limited. $^{2}$

Given that the literature on job loss has shown that job displacement leads to significant negative effects on earnings, health and mortality, children's educational achievement and infant health (Jacobson, LaLonde and Sullivan, 1993; Stevens, 1997; Sullivan and Von Wachter, 2009; Oreopoulos, Page and Stevens, 2008; Lindo, 2011), UI could play an important role in mitigating these effects. In this paper, I concentrate on previously unexamined potential benefits of UI on the wellbeing of its recipients by empirically estimating the effect of UI generosity on the health insurance coverage, health status and health risk behaviors of the unemployed. Understanding the health effects of UI is not only interesting because health represents an important aspect of individuals' wellbeing, but also because it creates important externalities, ${ }^{3}$ whose presence implies different optimal levels of UI benefits than those

\footnotetext{
${ }^{1}$ For example, see Farber and Valletta (2011); Rothstein (2011); Hagedorn et al. (2013); Schmieder, Von Wachter and Bender (2012); Chetty (2008); Landais, Michaillat and Saez (2010); Kroft and Notowidigdo (2016); Lalive, Landais and Zweimüller (2015).

${ }^{2}$ Many works on this subject focus only on measuring the effect of UI on consumption smoothing (Gruber, 1997; Browning and Crossley, 2001; Kroft and Notowidigdo, 2016; East and Kuka, 2015). To my knowledge, the only papers that analyze other possible benefits of UI are Hsu, Matsa and Melzer (2018) and Barr and Turner (2015), which examine the effect of UI on consumer credit markets and college enrollment, respectively.

${ }^{3}$ For example, while drinking and smoking lead to negative externalities on children, spouses and the neighborhood, improved mental health and increased healthy behaviors may have important positive spillovers
} 
previously found.

Previous research has shown that job loss is associated with negative effects on health. For example, Sullivan and Von Wachter (2009) find that displaced male workers in the U.S. experience a 50-100 percent increase in mortality rate in the years immediately following a job loss. Studies conducted in Northern Europe have found smaller but statistically significant increases in mortality (Browning and Heinesen, 2012; Eliason and Storrie, 2009). Other work has analyzed the mechanisms that cause this increase in mortality, finding that job displacement leads to negative effects on cardiovascular health, driven by increases in smoking (Black, Devereux and Salvanes, 2015). In addition, Schaller and Stevens (2015) show that job loss leads to reduced insurance coverage, self-reported health, and health utilization. It is important to note that the reported health effects have been found in the presence of current safety net programs and public health provisions, implying that these effects could be even larger in their absence.

Unemployment Insurance (UI) is likely to mitigate the negative health effects of job loss through different channels. First, UI can operate through an income effect. Higher UI payments may imply higher investments in health, leading to improved health, and/or increases in risky behaviors, such as smoking and alcohol consumption, which may lead to negative health effects. Thus my analysis contributes to the literature on the causal relationship between income and health. Second, individuals living in more generous UI states may experience less economic uncertainty, which reduces stress. Hence higher UI payments could lead to improved mental health and to decreases in smoking, alcohol consumption and illnesses associated with stress. Third, UI leads to longer unemployment spells and decreased time spent working, which could affect health through changes in time use. Overall, the expected effect of UI generosity on health is ambiguous.

My empirical strategy relies on exploiting plausibly exogenous variation in the level of UI payments caused by changes in state UI laws, similar to Gruber (1997). For this purpose, I have built a UI calculator for 1993-2015 based on state UI laws, which allows me to calculate the amount of UI that an individual is eligible for, given his individual earnings prior to unemployment and the number of children in the household. However, given that individual UI payments are a function of earnings and that earnings are correlated with health, using individual UI payments might lead to biased estimates of the effect of UI generosity on health. To avoid this possible bias, I create "simulated UI replacement rates", a measure of the generosity of the state UI program that depends only on state policy variation, and not

(Marcus, 2013; Yakusheva, Kapinos and Eisenberg, 2014). Moreover, the uninsured cause financial externalities to hospitals (and other providers) who bear the costs of providing them uncompensated care (Garthwaite, Gross and Notowidigdo, 2018; Finkelstein, Mahoney and Notowidigdo, 2017). 
on the characteristics of the sample of individuals unemployed in each state and year (Currie and Gruber, 1996a; Cohodes et al., 2016).

To generate the simulated replacement rates I use the 1996-2008 panels of the Survey of Income and Program Participation (SIPP), which contain detailed monthly employment and earnings information for a large sample of individuals. I identify individuals that have lost their job through no fault of their own at the beginning of their unemployment spell, and I calculate their earnings for the 12 month period prior to unemployment. I thus create a national, fixed sample of all job losers in the 1996-2013 period, and use this constant sample to calculate average replacement rates, equal to UI payment eligibility divided by weekly earnings, for each state, year and number of children cell.

After obtaining this measure of state UI generosity, I merge it to the individual observations in the 1996-2013 SIPP. The longitudinal aspect of the SIPP and the detailed information on reason for job separation allow me to construct a sample of involuntary job losers observed 12 months prior to 24 months after job loss. I then use an event study model to analyze how UI generosity affects individual UI benefits received and health insurance coverage, before and after job loss, after controlling for state and year fixed effects.

I also merge my measure of UI generosity to the 1993-2015 Behavioral Risk Factor Surveillance System (BRFSS). While this dataset is a only a repeated cross section of employed and unemployed individuals, and thus does not allow to follow job losers over time, it contains detailed information on a variety of important health outcomes, such as self-reported health, insurance coverage, risky behaviors, doctor visits and preventive care. I use this dataset to first estimate the effects of higher UI generosity on health with a state and year fixed effect model on the sample of the unemployed. Second, I estimate a triple differences model which adds employed individuals as a control group for the unemployed, which allows me to control for health shocks at the state and year level that affect the employed and unemployed equally.

The results obtained with the SIPP data show that a 1 standard deviation increase in UI generosity is associated with a $\$ 22$ increase in monthly UI benefits, and a 1.6 percent increase in health insurance coverage, which is driven by private health insurance coverage. Importantly, the event studies rule out differential pre-trends in insurance coverage, and show that UI only affects insurance status after job loss. Moreover, the results are robust to a variety of specification checks and placebo analyses.

The BRFSS results confirm the effects on insurance coverage, and show that higher UI generosity leads to increases in having a routine check-up, self-reported health, and having a breast exam. Moreover, these effects are stronger during periods of high unemployment rates, when the need for UI may be highest. Lastly, I find no strong evidence of significant 
short-term effects of UI on risky behaviors, such as alcohol consumption or smoking, nor on health conditions such as diabetes and blood pressure.

The rest of the paper is structured as follows. In Section 2 I provide some background information on the UI program and the relevant literature, while Sections 3 and 4 describe the data and the empirical methodology used. Section 5 contains the findings, including robustness and heterogeneity analyses. Finally, Section 6 concludes.

\section{Background}

\subsection{Unemployment Insurance}

Unemployment Insurance (UI) is a joint federal-state social insurance program that provides temporary cash payments to help alleviate economic hardship for individuals who experience job loss through no fault of their own. Although the program is federally mandated, it is administered at the state level and subject to state laws regarding eligibility for the program, as well as the level and duration of UI payments. Typically, individuals are eligible for up to 26 weeks of payments, but the Extended UI program provides additional weeks during periods in which states experience high unemployment rates. Moreover, Congress has the power to enact further extensions during recessions under the Emergency UI program, as it did during the Great Recession. ${ }^{4}$

The typical weekly UI statutory replacement rate, defined as the UI payment as a share of pre-unemployment weekly earnings, is 50 percent of such earnings (Kroft and Notowidigdo, 2016). However, each state establishes a nominal minimum and a maximum level of UI payments, as well as minimum earnings for eligibility for the program, making the actual replacement rate nonlinear in earnings. Therefore, individual replacement rates may vary significantly from the average. While the statutory earnings replacement rate and the dependent allowance are fairly constant within states over time, states change the maximum and minimum amounts of UI payments frequently, to either keep up with inflation or when UI funds are low (Smith and Wenger, 2013). Given these changes in the nonlinearity of the replacement rates, UI generosity varies within states across time. Moreover, some states provide small additional allowance for dependents (mainly children), ${ }^{5}$ which provides additional variation within states and across number of children. The identification strategy in

\footnotetext{
${ }^{4}$ In this paper I do not take advantage of the variation in the maximum weeks of UI eligibility, as these are often extended during period of recessions. Since recessions are associated with worse health (Ruhm, 2000), using this variation might lead to biased estimated effects of UI on health.

${ }^{5}$ As of 2014, fourteen states provide additional dependent payments. These are Arizona, Connecticut, Illinois, Maine, Maryland, Massachusetts, Michigan, New Jersey, New Mexico, Ohio, Pennsylvania, Rhode Island and Tennessee.
} 
this paper relies on taking advantage of these sources of variation in UI generosity.

Panel (a) of Figure (1) presents a map of the average simulated replacement rate in each state in 1993, the first year of my period of analysis. These simulated replacement rates are constructed using a fixed sample of the unemployed to calculate UI payment levels for each state and year, and therefore depend only on policy variation. ${ }^{6}$ While the average replacement rate for the $1993-2015$ period is 41 percent, with an average real $(\$ 2015)$ weekly benefit level eligibility of $\$ 205$, Figure (1) shows that there is substantial variation in UI generosity across states and regions. For example, Oregon and Michigan had the highest replacement rates, both above 52 percent, while California and Florida were among the least generous states, with replacement rates around 38 percent.

In Panel (b) of Figure (1) I show how these replacement rates changed between 1993 and 2015, the first and last years of my period of analysis. Again, this uses a constant sample of unemployed. This map shows that changes in UI generosity were geographically dispersed and not strongly correlated with the initial level of generosity (in 1993). For example, while California and Oregon experienced large increases in UI generosity, Michigan and Florida enacted decreases in generosity. Finally, to present a comprehensive overview of the variation in state UI laws over time, in Appendix Figure (B.1) I plot trends in average simulated replacement rates for each state and number of children, for the period between 1993 and 2015. ${ }^{7}$ These graphs illustrate the substantial variation in generosity across states, as well as the smaller, but still sizable variation across number of dependents and within states over time. My empirical strategy exploits this variation, and its exogeneity will be discussed below in Section 4.

\section{$2.2 \quad$ Relevant Literature}

This paper contributes to the literatures on the benefits of UI, job loss, and the effects of government programs on health. The first body of work analyzes the UI program and its optimal level of UI. In large part this literature focuses on analyzing the effect of UI on job search and unemployment duration, known as the moral hazard effect (Meyer, 1990; Katz and Meyer, 1990; Card and Levine, 2000; Lalive, Van Ours and Zweimüller, 2006; Farber and Valletta, 2011; Rothstein, 2011). This collection of work finds that higher UI payments and longer durations lead to reduced job search and longer unemployment spells. In addition, another part of this literature analyzes the differential effects of UI across varying liquidity

\footnotetext{
${ }^{6}$ More details regarding the construction of these replacement rates will be presented in Section 4 and in the Appendix.

${ }^{7}$ This figure is composed of one subfigure per state, each containing simulated replacement rates by number of children.
} 
constraints and business cycles (Card, Chetty and Weber, 2007; Chetty, 2008; Kroft and Notowidigdo, 2016; Schmieder, Von Wachter and Bender, 2012).

The literature on the benefits of UI is more limited and is primarily focused on the consumption smoothing benefits of the program (Gruber, 1997; Browning and Crossley, 2001; Kroft and Notowidigdo, 2016; East and Kuka, 2015). These studies show that higher UI payments lead to a smaller drop in consumption when an individual is laid off. Other work has found that increased UI generosity leads to lower precautionary savings, increased spousal labor supply, improvements in consumer credit markets, increased college enrollment, and decreased suicide rates (Engen and Gruber, 2001; Cullen and Gruber, 2000; Hsu, Matsa and Melzer, 2018; Barr and Turner, 2015; Cylus, Glymour and Avendano, 2014). Note that some of these effects could be mechanisms for improved health, as changes in labor supply and college enrollment could affect the availability of cheaper employer or college provided health insurance.

The two closest papers to my own are Brown (2010) and (Cylus, Glymour and Avendano, 2015), who analyze whether unemployment is associated with a loss of private health insurance coverage $^{8}$ or decreased self-reported health, respectively, and whether UI generosity plays a role in mitigating such effects. In this paper, I not only extend and improve upon their analyses, ${ }^{9}$ but I also study the effects of UI on health utilization, health status, and healthy behaviors, which are ultimately the main outcomes of interest for policy.

A second important and relevant strand of literature is the one analyzing the negative effects of job loss on health. ${ }^{10}$ For example, job displacement is associated with increased mortality (Sullivan and Von Wachter, 2009; Browning and Heinesen, 2012; Eliason and Storrie, 2009), which could be driven by decreased cardiovascular health (Black, Devereux and Salvanes, 2015), increased risky behaviors, including alcohol consumption, smoking and unhealthy eating (Deb et al., 2011; Classen and Dunn, 2012), and increased suicide risk and hospitalization due to mental health problems, as well as spending on antidepressants and related drugs (Kuhn, Lalive and Zweimüller, 2009).

\footnotetext{
${ }^{8}$ Unemployed individuals can use UI to purchase health insurance either in the private market or through their former employer (through COBRA).

${ }^{9}$ I use simulated replacement rates that are constructed with a fixed sample of unemployed that does not vary year by year. Moreover, I include state fixed effects and state specific linear time trends.

${ }^{10}$ The literature on job loss is extensive. This line of research has found that job displacement leads to significant earning losses in the year immediately following job loss, and that these losses persist in the long-run (Jacobson, LaLonde and Sullivan, 1993; Stevens, 1997; Davis and Von Wachter, 2011). Job loss has also been linked to other important family dynamics outcomes, such as increased spousal labor supply, increased probability of divorce, and decreased fertility (Stephens, 2002; Charles and Stephens, 2004; Lindo, 2010; Eliason, 2012). Moreover, job loss has important intergenerational repercussions, leading to decreased children's educational achievement and infant health (Oreopoulos, Page and Stevens, 2008; Rege, Telle and Votruba, 2011; Stevens and Schaller, 2011; Lindo, 2011).
} 
Another important mechanism that could lead to worsening health status is the loss of health insurance coverage incurred after displacement, since in the U.S. around 88 percent of insurance coverage is acquired through the workplace (Brown, 2010). In fact, Gruber and Madrian (1997) find that job loss leads to a 20 percentage point (p.p.) reduction in the probability of being covered by health insurance. Lastly, Schaller and Stevens (2015) use more recent data to confirm that job loss leads to reduced self-reported health, insurance coverage and health utilization. My paper will contribute to this literature by understanding how UI mitigates some of these negative effects.

Third, this paper contributes to the literature on the relationship between government programs and health. Studies of programs that directly provide health insurance and medical services find that Medicaid expansions for children and pregnant women can lead to increases in health utilization and improvements in infant health (Currie and Gruber, 1996a,b). Moreover, Medicaid expansions for low-income adults are associated with higher health care utilization, lower out-of-pocket medical expenditures and debt, improved self-reported health, although there are no short term effects on health conditions such as hypertension or high cholesterol (Finkelstein et al., 2012; Baicker et al., 2013).

Government programs can affect health not only through the direct provision of insurance and medical services, but also through income effects. For example, increases in government welfare and nutrition programs are associated with increased health insurance coverage, health utilization, and self-reported health (Bitler, Gelbach and Hoynes, 2005; Evans and Garthwaite, 2014; Hoynes, Page and Stevens, 2011; Hoynes, Schanzenbach and Almond, 2016). While part of this literature analyzes welfare programs due to interest in the effects of their specific characteristics on the target population, another is interested in these programs as income shifters, and it is ultimately interested in understanding the relationship between income and health. ${ }^{11}$ Given that UI provides temporary income to job losers, my work will provide further evidence on this relationship.

\footnotetext{
${ }^{11}$ Given the strong, positive correlation between income and health, many researchers are interested in analyzing its causality, and have used a variety of methodologies to do so. Apart from the methodologies that exploit welfare program expansions as income shifters, other researchers have exploited lottery winnings, inheritances, a rise in South African pensions, a social security notch, a drop in income due to crop damage, and changes in stock market prices (Lindahl, 2005; Meer, Miller and Rosen, 2003; Case, 2004; Snyder and Evans, 2006; Banerjee et al., 2010; Cotti, Dunn and Tefft, 2013). These studies find varied results, and do not reach a consensus on the causal relationship between income and health.
} 


\section{$3 \quad$ Data and Descriptive Statistics}

\subsection{Data Sources}

I use two main sources of data to analyze the effects of UI on health, each with its relative strengths, which I describe in detail below.

\subsubsection{SIPP}

The first main source of data are the 1996, 2001, 2004 and 2008 panels of the Survey of Income and Program Participation (SIPP), ${ }^{12}$ maintained by the U.S. Census Bureau. Each SIPP panel is a longitudinal survey that interviews a sample of representative households at four month intervals (waves) for 2.5 to 4 consecutive years. Importantly, the SIPP collects detailed information demographics, labor force participation, earnings, program participation and health insurance coverage, and it collects this information for each month in the period between interviews, allowing the construction of a detailed monthly (short) panel of individuals. Jointly, these panels contain information for the 1996-2013 time period. ${ }^{13}$

To be eligible for the UI program, an individual must lose his job without fault of his own. Therefore, to create the sample of interest, I identify individuals that lose a job through no fault of their own, defined as all individuals ages 18-60 who declare that the main reason for having stopped working for previous employer is: "on layoff", "employer bankrupt", "employer sold business" or "slack work or business conditions". I observe a total of 17,112 of such involuntary job losses in the 1996-2013 period. ${ }^{14}$ I then use the month and year of this job separation to identify the exact month of job loss, and to restrict the sample to observations 12 months before to 24 months after the job loss. Additionally, I create a post-displacement indicator that turns to one from this month onwards, as well as indicators for all (two-month) periods before and after job loss, which allow me to analyze in detail the differential effects of UI generosity before and after job loss, and how these evolve over time.

I also use the SIPP data to construct the measure of UI generosity. I identify involuntary job losers as above, and for each these individuals I collect information on quarterly earnings prior to job loss as well as demographics during the month of job loss. After excluding from the sample individuals with zero wage earnings, who could be self-employed and therefore

\footnotetext{
${ }^{12}$ I do not use earlier SIPP panels as do not contain information om reason for job separation, which is fundamental for my analysis.

${ }^{13}$ I exclude Maine, North Dakota, South Dakota, Vermont and Wyoming from the 1996 and 2001 panels, as these panels does not contain unique state identifiers for these states.

${ }^{14}$ There are a total of 93,539 job separations in this period, out of which 19,452 are involuntary. Moreover, if an individual experiences more than one unique episode of involuntary job loss, I use the first episode only, hence I am left with 17,112 events for the analysis.
} 
not eligible for UI, I am left with a sample of 14,238 unique individuals for which I have the information necessary to calculate UI generosity.

The SIPP data is the ideal dataset for my analysis for a variety of reasons. First, I use its longitudinal aspect and information of the date of job loss to conduct event study analyses of the effects on UI, providing visual evidence of the main identification assumption, as discussed in detail below. Second, the detailed information on reason of job separation allows me to create a sample of individual likely to be eligible for UI. Third, I use information on UI receipt to provide evidence of a positive relationship between my measure of UI generosity and UI receipt, and of the size of the "first-stage". Fourth, the detailed information on type of health insurance coverage allow me analyze whether UI affects insurance coverage through private or public (Medicaid) coverage. The main disadvantage of the SIPP is that I cannot analyze other health outcomes of interest, such as utilization, self-reported health, and risky behaviors. $^{15}$

\subsubsection{BRFSS}

The second main source of data is the Behavioral Risk Factor Surveillance System (BRFSS), a telephone based cross-sectional survey that collects information on the major personal health behaviors associated with the leading causes of death in the U.S., such as tobacco and alcohol use, diet, hypertension and diabetes. Although it began as a survey of only fifteen states in 1984, by 1993 the BRFSS had become a nationwide survey with at least 100,000 participants per year. For this reason, in this analysis I will concentrate on the 1993-2015 surveys only.

The survey is composed of core and optional modules, where the core module questionnaires are conducted in every state, and the optional ones are conducted only in the states that elect to do so. In my analysis I will mainly use data from the core modules, which include questions regarding health utilization, self-reported health, healthy or risky behaviors, and health conditions. Moreover, the core modules contain important demographic information, as well as current employment status and state of residence. The employment status variable asks responders whether they are currently employed for wages, self-employed, unemployed for less than one year, unemployed for more than one year, homemakers, students, retired, or unable to work.

The sample used for the analysis contains individuals who have been unemployed for less than one year, who are those more likely to be eligible for UI. Unfortunately, the BRFSS does

\footnotetext{
${ }^{15}$ While for a subsample of this data one could merge additional information from the SIPP topical waves that collect information on a few adult health outcomes, these questionaries are administered only once or twice in each panel, not allowing for a longitudinal analysis.
} 
not separately identify individuals that are unemployed because of job loss, or those who quit their previous jobs or are new entrants into the labor force. Therefore my unemployed sample is composed of both UI eligible and non-eligible individuals, which may lead to measurement error. In addition to those unemployed for less than one year, my sample also includes individuals who are currently working for wages, who act as a control group in some of the empirical specifications. Finally, I restrict my sample to individuals aged 18 to 60 , similar to the SIPP, and I exclude all individuals with missing demographic information. After these restrictions, the unemployed and employed samples include 144,993 and 2,678,294 individuals, respectively.

\subsubsection{Other sources}

To calculate UI weekly benefit eligibility in the SIPP, I use a UI calculator containing data on state UI laws that I constructed from a variety of sources. The main information was collected from the Employment and Training Administration, which reports semi-annual information on state payment schedules. Moreover, I supplemented this data with information from the calculators used in LaLumia (2013), Chetty (2008) and Gruber (1997), as well as other state laws and documents. As explained above, the formula used to calculate payments varies by state and year, and includes the percent of earnings to be replaced by UI, a minimum and maximum amount of weekly payments, and a minimum amount of earnings required for eligibility to the program. ${ }^{16}$ In addition, some states have an additional allowance depending on the number of children of the unemployed individual, which are incorporated into the calculations.

Finally, I use data on state economic conditions, safety net per capita expenditures, and state safety net eligibility in order to control for possible state-level confounders. Appendix B.3 contains detailed descriptions and sources for these data.

\subsection{Descriptive Statistics}

Panel (a) of Table (1) contains summary statistics for the main demographics in the SIPP and BRFSS samples, while Panel (b) contains statistics on the main outcomes of interest. In each panel, the first column presents information for the main sample of job losers in the SIPP, observed 12 months before to 24 months after job loss. The second column provides statistics for the SIPP sample used to calculate UI generosity, hence it contains one observation per

\footnotetext{
${ }^{16}$ The methods to calculate UI eligibility vary considerably across states, and may dependent on annual earnings, quarterly earnings, or number of hours worked. For more information on state UI laws, see the Appendix.
} 
job loser and at the time of job loss. The last two columns contain summary statistics for the BRFFS sample, separately for unemployed and employed workers.

Panel (a) shows that involuntary job losers and the unemployed are more likely to be younger and male relative to the employed. They also tend to be more disadvantaged, as demonstrated by the higher likelihood of being black and the lower likelihood of having a college degree and being married. Moreover, column (2) shows that in the year prior to job loss, average annual earnings of involuntary job losers were $\$ 32,357$. Panel (b) shows that average monthly UI in the main SIPP sample, for individuals observed 12 months before to 24 after job loss is substantial, and equal to $\$ 145$. Moreover, it shows that job losers and the unemployed fare worse relative to the employed among a wide set of health outcomes, such as insurance coverage, health utilization, self-reported health, and risky behaviors.

Before moving to the discussion of the empirical strategy, I provide some descriptive evidence from the SIPP to motivate the main analysis. To do so, for each involuntary job loser in the 1996-2013 SIPP I calculate a) their simulated replacement rate, the measure of UI generosity, in the month of job loss, and b) the difference in UI benefits and insurance coverage in the 24 months after relative to the 12 months before job lob loss.

In Figure (2) I plot the linear relationships between the two, as well as the underlying data grouped in 20 equal-sized bins. The figure shows striking patterns, with a 10 p.p. increase in the replacement rate being correlated to a $\$ 89$ and 1.3 p.p. increase in monthly UI and health insurance coverage. These relationships contain variation stemming also from cross-state differences, but my empirical strategy will mainly rely on within state variation. Hence, I next collapse the individual data to obtain state-year average replacement rates and differences in UI and insurance upon job loss. Figure (3) plots the long-term changes in these averages between 2013 and 1996, for each state separately. Again, the results show that larger increases in UI generosity are correlated with larger increased in UI benefits and insurance coverage, suggesting a causal role for UI.

\section{Empirical Strategy}

My overall identification strategy relies on variation in UI generosity within states and across number of children and time that is driven by changes in state UI laws. In this section, I first describe how I construct this measure, then I describe the empirical specifications that I employ for each of my two main data sources, and last I discuss possible threats to identification. 


\subsection{Simulated UI Replacement Rate}

To measure state UI generosity, I use the SIPP sample of all individuals that are observed in the first month of their unemployment spell between the years 1996-2013. This sample is therefore a national, fixed sample that does not vary across states and years. I then use information on pre-unemployment earnings ${ }^{17}$ and number of children for this fixed sample to calculate UI eligibility for each individual in each state and in each year. Once I calculate each individual's UI weekly payments, I divide these payments by the individual's weekly earnings to obtain a simulated replacement rate. Finally, I collapse the data to the year, state and number of children cell, ${ }^{18}$ and I calculate average simulated replacement rates for each cell, $R R_{c s t}$. These measures are all shown in Appendix Figure (B.1)

Simulated measures of program generosity have been widely used in the literature, as they provide variation that is not due to individual characteristics but states' legislative environment only (Currie and Gruber, 1996b; Gruber, 1997; Moffitt and Wilhelm, 1998; Cohodes et al., 2016). ${ }^{19}$ This is important in the case of UI, since its payment formula is a nonlinear function of individual earnings, with higher earnings implying lower replacement rates due to the maximums in UI levels. Given that higher earnings are correlated with improved health, using individual replacement rates without fully controlling for earnings might lead to downward biased estimates of the effect of UI on health.

\subsection{SIPP}

Given that the SIPP is a longitudinal survey, for which I created a panel of job losers observed 12 months before to 24 months after job loss, I assign each job loser a simulated replacement rate according to the year, state and number of kids in the month of their job loss. I then estimate the following specification:

$$
\begin{aligned}
H_{i c s t}= & \alpha_{i}+\beta_{1} R R_{c s t} * L_{i c s t}+\beta_{2} L_{i c s t}+\gamma_{1} X_{i c s t}+\gamma_{2} Z_{s t}+\nu_{c} * L_{i c s t}+ \\
& \theta_{t} * L_{i c s t}+\delta_{s} * L_{i c s t}+\lambda_{s} * t+\epsilon_{i c s t}
\end{aligned}
$$

where $i, c, s$, and $t$ represent individual, number of children, state and year, respectively. $H$ is the health outcome of interest, $R R$ is the simulated replacement rate, and $L$ is an indicator equal to 1 in the 24 months after job loss. $X$ includes demographic controls, such as indicators for age, marital status, gender, race, ethnicity, education and calendar month of interview, while $Z$ includes cubic polynomials for the state unemployment rate and the state

\footnotetext{
${ }^{17}$ Earnings are adjusted for inflation.

${ }^{18}$ The number of children variable takes the value of 4 for individuals with 4 or more children.

${ }^{19} \mathrm{An}$ additional benefit of a simulated instrument is that it provides one unique measure of program generosity that includes all the features of state policies.
} 
average annual wage. ${ }^{20} \mathrm{I}$ also include individual fixed effects $\alpha_{i}$, as well as fixed effects $\nu_{c}, \theta_{t}$, $\delta_{s}$, all three allowed to differ before and after job loss, to control for permanent differences in outcomes across years, states and number of children, separately for individuals prior and after job loss. Finally, I include $\lambda_{s} * t$, which controls for state-specific linear time trends. All regressions are weighted using sampling weights, and the standard errors are clustered at the state level.

In this model, $\beta_{1}$ is the main coefficient of interest, representing the differential effect of UI after job loss, when the individual is eligible for UI. Importantly, given that I include individual effects, the analysis exploits within-individual variation in health. ${ }^{21}$ Moreover, after controlling for $\nu_{c} * L, \theta_{t} * L$ and $\delta_{s} * L$, the remaining major sources of variation in UI generosity that I use for identification are differences in UI generosity within states across number of children, and within states over time. Thus one of the main identification assumptions is that these differences in state UI generosity are not correlated with other factors that affect individual changes in health outcomes upon job loss.

Note that the longitudinal aspect of the data also allows for a more flexible, and convincing, model relative to Equation (1). For all baseline results, I estimate event study analyses similar to Jacobson, LaLonde and Sullivan (1993) by creating dummy variables for each month in the unemployment spell, and interacting these dummies with the replacement rate, with all other aspects of the models identical to Equation (1). This specification allows me to estimate the differential impacts of UI in each month prior and after job loss, providing compelling evidence of the absence of differential pre-trends, the other main identification assumption in the analysis.

\subsection{BRFSS}

The BRFSS sample contains repeated cross sectional observations of unemployed and working individuals. Thus, I assign simulated replacement rates according to the year, state and number of children at the time of observation. I start by estimating the following state and year fixed effects model for the sample of unemployed individuals only:

$$
H_{i c s t}=\beta_{0}+\beta_{1} R R_{c s t}+\gamma_{1} X_{i c s t}+\gamma_{2} Z_{s t}+\nu_{c}+\theta_{t}+\delta_{s}+\lambda_{s} * t+\epsilon_{i c s t},
$$

where all variables are identified as in equation (1). Also in this model, $\beta_{1}$ is the main coefficient of interest, as it represents the average effect of UI among unemployment individ-

\footnotetext{
${ }^{20}$ If states change UI laws because of low UI funds or adverse economic conditions, flexibly controlling for such conditions may be important. Below I explain this in detail.

${ }^{21} \mathrm{My}$ specification does not include a main effect on $R R_{c s t}$ since this is absorbed by the individual fixed effects.
} 
uals. This analysis thus exploits across state, year and number of children variation in the health of the unemployed, with the main assumption being that changes in state UI laws are uncorrelated with other state health shocks.

Second, I employ a triple differences methodology, which uses the sample of employed individuals as a control group for the unemployed. This relies on the assumption that the employed are not affected by UI laws, and that the two groups have similar trends in health. By adding this group of individuals I can estimate triple differences regressions of the following form:

$$
\begin{aligned}
H_{i c s t}= & \beta_{0}+\beta_{1} R R_{c s t}+\beta_{2} R R_{c s t} * U_{i c s t}+\beta_{3} U_{i c s t}+\gamma_{1} X_{i c s t}+\gamma_{2} Z_{s t}+ \\
& \nu_{c} * U_{i c s t}+\theta_{t} * U_{i c s t}+\delta_{s} * U_{i c s t}+\lambda_{s} * t+\epsilon_{i c s t}
\end{aligned}
$$

where $U$ is an indicator that is equal to 1 if the individual is currently unemployed, and 0 if he is working. $\nu_{c} * U, \theta_{t} * U$ and $\delta_{s} * U$ represent differential number of children, state and year fixed effects for the unemployed and the employed groups. In this model the effect of UI is captured by $\beta_{2}$, which represents the differential effect of UI for the unemployed compared to the employed. These triple differences also allow for the inclusion of state-byyear-by-number of children fixed effects, which I include in parts of analyses to better absorb health shocks that are common to the two groups.

The triple differences model has some benefits and drawbacks relative to the state and year fixed effects model. The inclusion of the employed allows me to control for state level health shocks and differences in health by number of children across states that affect the employed and unemployed equally. Moreover, the main identification assumption in these triple differences models is that changes in state UI laws are uncorrelated with state level shocks that affect the unemployed differentially from the employed. The assumption in this model is indeed weaker than that of the state and year fixed effects one.

However, there is also a potential drawback to this method. If employed individuals are partially treated by UI, the estimated effects obtained with a triple differences model will lead to effects that are biased towards zero. Employed individuals may be treated by UI through different channels. First, employed individuals could be receiving UI through other members of the household who could be unemployed. Second, the stress of the employed could be reduced because of higher UI generosity even if they do not receive UI payments, as larger UI generosity may reduce the uncertainty and stress associated with the possibility of becoming unemployed. Third, larger UI payments could lead to longer job search and better job quality, which could improve health either through direct provision of health insurance coverage or through increased wages (Nekoei and Weber, 2017). 


\subsection{Threats to Identification}

Both SIPP and BRFSS empirical analyses rely on the assumption that differences in UI generosity within states are not correlated with other factors that affect changes in health status and utilization upon job loss. For example, one could worry that the relationship between health and number of children is different across states, and correlated to differences in state UI generosity across number of children. ${ }^{22}$ Not only does this story not seem very plausible, but also note that the BRFSS triple difference analysis controls for such differences.

A second possible worry could be that state legislators change UI generosity during periods of recessions, which also affect individual health. To rule out this type of concern, I test whether UI generosity is correlated to state-level economics conditions. I use a state and year panel to estimate a model where the dependent variable is $R R_{s t}{ }^{23}$ the measure of UI generosity, and the independent variables are measures of state economic conditions, such as unemployment rates, average weekly wages and employment rates, all allowed to take cubic forms. All regressions include state and year fixed effects as well as state specific linear time trends, ${ }^{24}$ and these results are shown in Table (2).

Overall, the results suggest no significant relationship between these economic conditions and UI generosity. For example, column (1) shows that a 1 p.p. increase in the unemployment rate is estimated to lead to a statistically insignificant 0.1 p.p. decrease in the simulated replacement rate. sAppendix $\mathrm{C}$ contains a more thorough discussion, and further evidence, on the relationship between state economic conditions and UI generosity. In summary, the only evidence I find for such relationship is that lagged economic conditions are correlated with UI laws, implying that state legislators might decrease UI generosity if the state just went through a downturn and the trust fund balances are low. In sensitivity checks, I will show that flexibly controlling for lagged economic conditions does not affect the results.

One could also be worried that changes in UI generosity occur contemporaneously to changes in eligibility for other safety net program, in which case $\beta_{1}$ would not capture the effect of UI only. Hence I next analyze the relationship between state UI generosity and other state-level policies and expenditures, with results shown in Panels (a) and (b) of Table (3), respectively. These results suggest that, after controlling for the vector $Z_{s t}$, state and year fixed effects and state specific linear time trends, UI replacement rates are exogenous to the size and generosity of the state safety net. The only statistically significant result

\footnotetext{
${ }^{22}$ In sensitivity analysis I will show that adding state-by-number of children-by job loser fixed effects does not affect the SIPP estimates.

${ }^{23} R R_{s t}$ is a (state by year) weighted average of the simulated replacement rate $R R_{c s t}$.

${ }^{24} \mathrm{Hsu}$, Matsa and Melzer (2018) conduct similar tests and confirm that these laws are not correlated to states' current UI trust fund balances, state unemployment rates, average earnings, GDP growth, or home price growth.
} 
is that UI generosity is correlated to higher AFDC/TANF maximum benefits, although it is not correlated to AFDC/TANF spending. Importantly, and as expected, higher UI replacement rates are correlated with higher maximum level of UI benefits and higher UI spending. Lastly, as UI generosity varies also across the number of children, Appendix C provides further analyses of the relationship between UI and state economic conditions and spending at the state-year-number of children level. These results are similar to the ones at the state-year level only.

Another possible threat to identification may be due to selection, since the BRFSS analysis is cross-sectional in nature, and I can only identify individuals that are employed or unemployed at the time of the interview. In fact, even if state UI laws are exogenous, the sample of the unemployed may be endogenous to UI, as prior literature has shown that higher UI benefits lead to longer unemployment spells (Katz and Meyer, 1990; Farber and Valletta, 2011; Rothstein, 2011; Kroft and Notowidigdo, 2016). One might then worry that changes in sample composition might be driving the results. The results from the SIPP analysis, however, greatly alleviate these concerns, as the individual fixed effects control for unobserved preferences for health insurance coverage. Nevertheless, I will adress this issue further in Section 5.3.

\section{Results}

\subsection{SIPP Analysis}

\subsubsection{Main Effects}

Figure (4) presents coefficients from the event study analysis estimating the effect of UI generosity on monthly UI benefits received, the "first-stage" relationship. Reassuringly, I find zero effects of UI prior to job loss, and an immediate increase in UI benefits upon job loss. This increase is smaller in the first two months, as applying and obtaining UI benefits may not be immediate, and largest in months 3 to 6 since job loss. Note that after month 6 , the effect of UI generosity decreases, as job losers find new employment and UI benefits start to expire.

Panel (a) of Figure (5) contains event study results when analyzing the likelihood of health insurance coverage, and shows that higher UI generosity does not affect insurance coverage prior to job loss, but leads to a significant increase in insurance after job loss. Panels (b) and (c) show that these results are mainly driven by an increase in private health insurance, and not by Medicare/Medicaid. Importantly, none of the outcomes display trends prior to job loss, satisfying one of the major assumptions in these types of analyses. 
Table (4) contains the results obtained when estimating the average effect of UI after job loss, as in Equation (1). I estimate that 10 p.p. increase in the replacement rate leads to statistically significant $\$ 45,2.1$ p.p. and 1.5 p.p. increases in monthly UI benefits, any health insurance coverage, and private insurance coverage, respectively, and to a statistically insignificant 0.8 p.p. increase in public insurance. Given that in my sample the standard deviation of the UI replacement rate is 5 percentage points and that average insurance coverage is 64 percent, my results imply that a 1 standard deviation increase in UI generosity leads to a 1 p.p. (or 1.6 percent) increase in health insurance coverage.

To put these results into perspective, it is useful to calculate the propensity to consume health insurance out of UI. Comprehensive data on premium prices for non-group - not employer nor government provided - health insurance is scarce. I use information from Kaiser Family Foundation reports (KFF, 2004, 2010) to estimate that average insurance premiums cost between $\$ 299$ and $\$ 531$ a month. ${ }^{25}$ This implies that a $\$ 100$ increase in monthly UI receipt leads to an increase in health insurance spending of \$15-24. Another useful exercise is to compare the health insurance effects of UI to those from another income transfer program, the EITC. Hoynes, Miller and Simon (2015) estimate that the 1993 EITC expansion led to $\$ 1000$ and 3.6 p.p. increase in (annual) EITC and health insurance coverage, effects of similar magnitude to the ones I estimate for UI.

\subsubsection{Specification Checks}

Panels (a) and (b) of Table (5) show results from specification checks for the two main SIPP outcomes. In column (1) I present the baseline results shown in Table (4), and in column (2) I show that excluding individual fixed effects does not significantly affect the estimates. In columns (3) and (4) I omit state-specific linear time trends and controls for economic conditions, respectively. In column (5) I show results from regressions that include additional, flexible controls for lagged economic conditions, ${ }^{26}$ and in column (6) I include as additional controls the state safety net generosity variables contained in Panel (a) of Table (3). These results suggest that the estimated effects are not sensitive to the inclusion or

\footnotetext{
${ }^{25} \mathrm{KFF}$ (2004) contains information from 2003 data from eHealthInsurance.com, the largest vendor of nongroup insurance in the period, and shows that the average monthly premium for this type of insurance was $\$ 192$ and $\$ 358$ (2015\$) for individual and family plans, respectively. (KFF, 2010), a 2010 survey of people who purchase their own insurance, shows that self-reported individual and family monthly premiums average $\$ 327$ and $\$ 643$, respectively. Given that $35.5 \%$ of my sample is single and childless, I assume they would purchase individual plans, while the remaining job losers would buy family plans. Hence, I calculate the average monthly plan to cost between $\$ 299$ and $\$ 531$. Note that these insurance costs are substantially lower then total premiums for employer provided insurance, which likely reflects the fact that non-group insurance may provide lower benefits (KFF, 2004).

${ }^{26}$ Specifically, I include cubic polynomials for the 1 and 2-year lags of both the state unemployment rate and net UI reserves.
} 
exclusion of state-level controls.

In column (7) I test the importance of allowing the state, year and number of children fixed effects to differ prior and after job loss. While the qualitative results remain the same, omitting these controls changes the magnitude of the effects. Given the obvious differences in UI receipt between job losers and the employed, who are not eligible for UI, fixed effects that do now allow for differential effects by employment status may not be able to fully capture fixed state differences in UI receipt, suggesting that these types of controls may be fundamental.

In columns (8) to (11) I show the sensitivity of the results to including children-by-yearby-job loss, children-by-state-by-job loss and state-by-year-by-job loss fixed effects, which absorb various portions of the overall variation in UI generosity. The results show that including the first two sets of fixed effects separately does not significantly affect the results, but that including state-by-year-by-job loss fixed effects, which absorb all variation within states over time, reduces the coefficient on UI, rendering it statistically insignificant although still positive. When I include all three sets of fixed effects jointly, in the last column, the coefficient on health insurance coverage loses statistical significance, suggesting that these fixed effects might absorb too much of the overall variation in UI. Reassuringly, the coefficient remains of a similar magnitude as the baseline.

Given that Appendix Figure (B.1) shows that UI generosity increased significantly during the Great Recession, due to both national and state-level policies, one might worry that this period is spuriously driving all the results. Appendix Table (A.1) provides evidence against this threat, as it shows that the baseline results are not sensitive to dropping years 2008-2010 from the analysis.

Next, I conduct placebo tests where I analyze the effects of UI individuals that experience a job separation, but who are less likely to be eligible for UI. Columns (1) and (2) contain the baseline results for involuntary job losers. In the next two columns, I present results when analyzing individuals that quit their job to start a new employment. Among this set of individuals, higher UI generosity leads to small, negative and statistically insignificant effects on UI receipt and health insurance coverage after the job separation. In the last two columns I include all individuals that experience a job separation during the SIPP panel, but whose separation is not due to not an involuntary job loss nor due to quitting to take another job. ${ }^{27}$ Again, higher UI generosity does not lead to statistically significant increases in UI receipt nor health insurance.

\footnotetext{
${ }^{27}$ Reasons for these separations are varied, for example retirement, childcare or family obligations, illness and injury, schooling, being fired, etc.
} 


\subsection{BRFSS Analysis}

\subsubsection{Main Effects}

The results in the prior subsections provide causal evidence that UI leads to increased health insurance coverage among job losers, and rule out a variety of possible threats to identification. Given my interest in understanding also whether UI affects utilization and other health outcomes, for the remainder of the analysis I will focus on the results obtained with the BRFSS data.

I present the results for health insurance coverage and health utilization in Table (7). This table contains three separate panels. In Panel (a) I present the results obtained when estimating the state and year fixed effects model on the unemployed sample. Panel (b) displays the results obtained with the triple differences estimation strategy. In this set of results, the coefficient on the replacement rate represents the effect of UI on the employed, while the coefficient on the interaction between the replacement rate and the unemployed indicator captures the differential effect of the replacement rate on the unemployed. Finally, Panel (c) shows the results obtained when estimating triple differences models that include state-by-year-by-number of children fixed effects, which absorb the main replacement rate effect.

In column (1) of Table (7) I analyze whether UI generosity affects the likelihood of (any) health insurance coverage. Panel (a) shows that a 10 p.p. increase in the simulated replacement rate leads to a statistically significant 3.3 p.p. increase in the likelihood of having insurance. This effect is larger in size that the one estimate with the SIPP, but within its confidence interval. Panels (b) shows a small but statistically significant effect of UI on the health insurance of employed individuals, and a large, significant differential effect on the unemployed. As mentioned previously, it is plausible that the employed might be affected by UI generosity through multiple channels. If the employed are indeed partially treated by UI, then the coefficients on the interaction between the replacement rate and the unemployed are a lower bound of the effect of UI. Lastly, Panel (c) shows that adding state-by-year-by-number of children fixed effects does not alter the estimated effects on the unemployed, implying that changes in UI laws are not correlated to average state-level health shocks.

Column (2) shows results for the effect of UI on the likelihood of having a routine checkup in the last year. The results are consistent across the three panels and show that a 10 p.p. increase in the replacement rate leads to around 3.4 p.p. increases in the likelihood of having a routine checkup. Again, adding state-by-year-by-number of children fixed effects does not greatly affect the estimates. The results obtained when analyzing the effect of UI on the 
probability of affording a doctor when needed, which I present in column (3), are instead statistically insignificant.

I also analyze whether higher UI payments lead to increased clinical breast exams (CBE), which are physicals exams performed during routine medical checkups that can improve the chance of early breast cancer detection. The BRFSS contains information on whether the respondent ever had a breast exam and whether she had one in the last year. I expected increased routine checkups in the last year to also increase breast cancer screenings in the same period. On the other hand, I do not expect UI to have a strong effect on the likelihood of ever having a CBE, and this can act as a placebo test. Indeed, the results show that a 10 p.p. increase in the replacement rate leads to a 5 p.p. increase in the probability of having a CBE in the last year and to a small, statistically insignificant effect on the probability of ever having such an exam.

In Table (8) I present the results for self-reported health. The first variable of interest is general health status, which I analyze as a continuous variable (1-5), as an indicator for being in good, very good or excellent health, or as an indicator for being in excellent health. In addition, I analyze the number of days in which the respondent felt physically or mentally healthy. For this analysis I use as outcomes both the number of days on which the respondent felt healthy, and whether they were healthy during the whole month. It is important to note that while subjective, measures of self-reported health are good predictors of mortality (Idler and Benyamini, 1997; DeSalvo et al., 2006).

The estimated effects are imprecisely estimated, with effects on self-reported health that are generally statistically significant at the 10 percent level. For example, the results in Panel (c) suggest that higher UI generosity leads to statistically significant 0.023 increase in general health and a marginally significant 0.85 p.p. increase in the likelihood of being in excellent health. These results are in in line with (Cylus, Glymour and Avendano, 2015), who find that higher state UI maximum payments lead to improved self-reported health for those experiencing job loss. The results obtained when analyzing the number of days in which the respondent felt physically or mentally healthy are mixed, with some evidence of improved physical health among the unemployed.

Appendix Table (A.2) presents results obtained when analyzing risky behaviors such as BMI, smoking, alcohol consumption, and pregnancies. These results suggest that higher UI generosity does not lead to significant changes in the likelihood of obesity (defined as having BMI of 25 or larger), smoking behavior or pregnancy. The only significant effect is on binge drinking, defined as the number of days in a month having at least 5 drinks, where I estimate that a 10 p.p. increase in UI generosity leads to a 0.17 increase in the number of days the unemployed binge drink. 
I also analyze a variety of other health outcomes contained in the BRFFS, such as health conditions (high blood pressure, high cholesterol and diabetes), and female cancer prevention (mammographies). The analysis of these outcomes does not generally yield significant results, therefore I do not presents most of those results here. There are two explanation for these results. First, the zero results could be driven by real null effects of the program. Second, these health effects could be impossible to detect in the short-run, as these health conditions may need a longer time to develop. Importantly, my findings are similar to (Finkelstein et al., 2012), who find that in the short-run providing free Medicaid to low-income adults increases their health utilization and self-reported health, but it does not lead to short-term improvements in health conditions.

\subsubsection{Heterogeneity Analyses}

Next, I explore whether the estimated effects on health insurance, utilization and selfreported health found in the BRFSS are differential across business cycles. East and Kuka (2015) provide evidence that UI's consumption smoothing effects are concentrated among individuals unemployed during the worst local economic conditions. Possible explanations for this finding are that UI payments are extended during periods of recessions and that UI take-up rates increase with the unemployment rate, which imply that during recessions increases in UI generosity are experienced for more months and among more individuals. These mechanisms may also generate similar differential effects across cycles on health. If take-up is higher, or the duration of payments is greater, the total amount of income received increases, which could potentially compound the income effects. In addition, since the bad state of the economy may lead to more uncertainty and higher stress levels for those experiencing job loss, UI may play an even larger role in attenuating these negative effects.

In order to explore differential effects across cycles, I create two dummy variables that indicate whether the respondent lives in a state and year with an above or below median average state unemployment rate. ${ }^{28}$ I interact these indicators with the simulated replacement rate. Panels (a) and (b) of Table (9) show these results for the unemployed sample and the triple differences sample, respectively.

These findings suggest that indeed UI leads to larger beneficial effects on all outcomes of interest during periods of high unemployment rates compared to periods with low unemployment rates, although these coefficients are not always statistically significantly different from each other (as shown by the p-values obtained from testing the equality of the two coefficients). Interestingly, the effects on self-reported health are statistically significant during

${ }^{28}$ The median unemployment rate is created using state-year observations and weighting by the state population. For the 1993-2015 period, the median unemployment rate is 5.5 p.p.s. 
periods of high unemployment rates, when a 10 p.p. increase in UI generosity is estimated to lead to a 1-1.6 p.p. increase in the likelihood of feeling in excellent general health.

In Table (A.3) I analyze whether the results are heterogenous across demographic groups, each panel containing results for one of the main health outcomes of interest. The results on health utilization show generally similar effects of UI generosity across gender and marital status, as well as smaller effects for unemployed individuals that have a college degree, have children, or live in states that are below median in their Medicaid generosity. Since UI is included as income in the calculation of Medicaid eligibility, UI may crowd-out Medicaid in states that do not have generous Medicaid programs. On the other hand, the effect of UI on self-reported health status is larger among individuals living in the least generous Medicaid states. $^{29}$

\subsection{Issues of Selection}

One possible concern with my identification strategy is that, even if state UI laws are exogenous to the health status of the state population, the sample of the unemployed in the BRFSS may be endogenous to such laws. For example, prior literature has shown that higher UI payments levels and UI extensions are associated with a decrease in job search and a decrease in the rate of unemployment exit (Katz and Meyer, 1990; Farber and Valletta, 2011; Rothstein, 2011; Kroft and Notowidigdo, 2016). If this moral hazard effect is correlated with health, the measured effects of UI on health may be biased by changes in sample composition. Note, however,s that this concern is not relevant for the SIPP analyses, as they include individual fixed effects and thus control for fixed individual characteristics and health.

For sample selection to bias the BRFSS estimates, it must be correlated with unobserved characteristics that also affect health. Because I cannot explicitly test for changes in unobserved characteristics, I analyze whether the observed characteristics of my BRFSS (and SIPP) samples are changing with UI generosity. The characteristics that I analyze are number of individuals in each state-year-number of children cell, as well as individual characteristics such as gender, age, education, and race. Panels (a) and (b) of Table (10) contain results for unemployed and employed individuals in the BRFSS, and Panel (c) contains results for job losers in the SIPP. The results show that UI generosity is not significantly correlated with the observed characteristics of the samples, as only two coefficients out of 24 are statistically significant. This suggests that UI generosity might also not be correlated with unobserved characteristics. Interestingly, a 10 p.p. increase in the simulated replacement

\footnotetext{
${ }^{29}$ These results are only suggestive, and not causal, as states that are more or less generous in Medicaid are different among many other dimensions.
} 
rate is associated with a statistically significant 1.8 p.p. decrease in probability of being a female among the unemployed. This effect is not surprising, as males traditionally have higher UI participation rates, and therefore are more likely to respond to changes in UI. ${ }^{30}$

\section{Conclusion}

The depth of the Great Recession combined with the legislated expansions to the Unemployment Insurance (UI) program resulted in UI being the largest safety net program during this period. Despite the importance of this program as part of the U.S. safety net, little is known about its benefits and whether the program mitigates some of the negative effects of job loss. Given that job loss has been associated with decreased health and increased mortality, this paper analyzes whether UI leads to improved health among unemployed individuals. I expect these health effects to be driven by several mechanisms: increased income, reduced economic uncertainty and stress, and changes in time use.

To empirically estimate these effects, I use data from both the 1996-2008 panels of the Survey of Income and Program Participation (SIPP) and the 1993-2015 Behavioral Risk Factor Surveillance System (BRFSS). The empirical strategy exploits exogenous yearly variation in state UI laws that are primarily driven by changes in the nonlinearity of payments with respect to earnings. As a measure of UI generosity, I use a fixed, national sample from the SIPP to calculate state simulated average generosity, which depend only on the UI laws and not on the characteristics of the unemployed. The results show that higher UI generosity is associated with increased UI benefits, health insurance coverage and health utilization. These effects are stronger during recessions, when job uncertainly and its related stress are higher. Moreover, during recessions UI also leads to improved self-reported general health status. Lastly, these results are robust to a variety of specification checks conducted with both the BRFSS and the SIPP.

My findings suggests that UI plays an important role in mitigating some of the negative health effects of job loss. Such improvements in health utilization and self-reported health are important as they may lead to significant positive health externalities on the family and the neighborhood, as well as decreased financial externalities on hospitals and insurers who subsidize the emergency hospital visits of the uninsured. Moreover, the results suggest that the Baily-Chetty canonical model for optimal UI (Chetty, 2006), which ignores externalities, may underestimate the optimal level of UI benefits.

\footnotetext{
${ }^{30}$ In heterogeneity analyses, I analyzed the differential effects of UI by gender, and the results showed that the effects are similar across males and females.
} 


\section{References}

Baicker, Katherine, Sarah L Taubman, Heidi L Allen, Mira Bernstein, Jonathan H Gruber, Joseph P Newhouse, Eric C Schneider, Bill J Wright, Alan M Zaslavsky, and Amy N Finkelstein. 2013. "The Oregon experiment? Effects of Medicaid on clinical outcomes." New England Journal of Medicine, 368(18): 1713-1722.

Baily, Martin Neil. 1978. "Some aspects of optimal unemployment insurance." Journal of Public Economics, 10(3): 379-402.

Banerjee, Abhijit, Esther Duflo, Gilles Postel-Vinay, and Tim Watts. 2010. "Long-run health impacts of income shocks: wine and phylloxera in nineteenth-century France." The Review of Economics and Statistics, 92(4): 714-728.

Barr, Andrew, and Sarah Turner. 2015. "Out of work and into school: Labor market policies and college enrollment during the Great Recession." Journal of Public Economics, 124: 6373 .

Bitler, Marianne, and Hilary Hoynes. 2016. "The More Things Change, the More They Stay the Same? The Safety Net and Poverty in the Great Recession." Journal of Labor Economics, 34(S1): S403-S444.

Bitler, Marianne P, and Hilary W Hoynes. 2010. "The State of the Social Safety Net in the Post-Welfare Reform Era." Brookings Papers on Economic Activity.

Bitler, Marianne P, Jonah B Gelbach, and Hilary W Hoynes. 2005. "Welfare reform and health." Journal of Human Resources, 40(2): 309-334.

Black, Sandra E, Paul J Devereux, and Kjell G Salvanes. 2015. "Losing heart? The effect of job displacement on health." ILR Review, 68(4): 833-861.

Brown, David. 2010. "Maintaining Health Insurance Coverage for the Unemployed: the Role of Unemployment Insurance."

Browning, Martin, and Eskil Heinesen. 2012. "Effect of job loss due to plant closure on mortality and hospitalization." Journal of Health Economics, 31(4): 599-616.

Browning, Martin, and Thomas F Crossley. 2001. "Unemployment insurance Benefit Levels and Consumption Changes." Journal of Public Economics, 80(1): 1-23.

Card, David, and Phillip B Levine. 2000. "Extended benefits and the duration of UI spells: evidence from the New Jersey extended benefit program." Journal of Public economics, 78(1): 107-138.

Card, David, Raj Chetty, and Andrea Weber. 2007. "Cash-on-hand and Competing Models of Intertemporal Behavior: New Evidence from the Labor Market." The Quarterly Journal of Economics, 122(4): 1511-1560.

Case, Anne. 2004. "Does money protect health status? Evidence from South African pensions." In Perspectives on the Economics of Aging. 287-312. University of Chicago Press. 
Charles, Kerwin Kofi, and Melvin Stephens. 2004. "Disability, job displacement and divorce." Journal of Labor Economics, 22(2): 489-522.

Chetty, Raj. 2006. "A general formula for the optimal level of social insurance." Journal of Public Economics, 90(10): 1879-1901.

Chetty, Raj. 2008. "Moral Hazard versus Liquidity and Optimal Unemployment Insurance." Journal of Political Economy, 116(2): 173-234.

Classen, Timothy J, and Richard A Dunn. 2012. "The effect of job loss and unemployment duration on suicide risk in the United States: a new look using mass-layoffs and unemployment duration." Health Economics, 21(3): 338-350.

Cohodes, Sarah R, Daniel S Grossman, Samuel A Kleiner, and Michael F Lovenheim. 2016. "The effect of child health insurance access on schooling: Evidence from public insurance expansions." Journal of Human Resources, 51(3): 727-759.

Cotti, Chad, Richard Dunn, and Nathan Tefft. 2013. "The Dow is killing me: risky health behaviors and the stock market." Social Science Research Network, 25.

Cullen, Julie Berry, and Jonathan Gruber. 2000. "Does Unemployment Insurance Crowd out Spousal Labor Supply?" Journal of Labor Economics, 18(3): 546-572.

Currie, Janet, and Jonathan Gruber. 1996a. "Health Insurance Eligibility, Utilization of Medical Care, and Child Health." The Quarterly Journal of Economics, 111(2): 431-466.

Currie, Janet, and Jonathan Gruber. 1996b. "Saving Babies: The Efficacy and Cost of Recent Changes in the Medicaid Eligibility of Pregnant Women." Journal of Political Economy, 1263-1296.

Cylus, Jonathan, M Maria Glymour, and Mauricio Avendano. 2014. "Do generous unemployment benefit programs reduce suicide rates? A state fixed-effect analysis covering 1968-2008." American journal of epidemiology, kwu106.

Cylus, Jonathan, M Maria Glymour, and Mauricio Avendano. 2015. "Health Effects of Unemployment Benefit Program Generosity." American journal of public health, 105(2): 317323.

Davis, Steven J, and Till Von Wachter. 2011. "Recessions and the Costs of Job Loss." Brookings Papers on Economic Activity, 43(2 (Fall)): 1-72.

Deb, Partha, William T Gallo, Padmaja Ayyagari, Jason M Fletcher, and Jody L Sindelar. 2011. "The effect of job loss on overweight and drinking." Journal of health economics, 30(2): 317-327.

DeSalvo, Karen B, Nicole Bloser, Kristi Reynolds, Jiang He, and Paul Muntner. 2006. "Mortality Prediction with a Single General Self-Rated Health Question." Journal of general internal medicine, 21(3): 267-275. 
East, Chloe N, and Elira Kuka. 2015. "Reexamining the consumption smoothing benefits of Unemployment Insurance." Journal of Public Economics, 132: 32-50.

Eliason, Marcus. 2012. "Lost jobs, broken marriages." Journal of Population Economics, 25(4): 1365-1397.

Eliason, Marcus, and Donald Storrie. 2009. "Does job loss shorten life?" Journal of Human Resources, 44(2): 277-302.

Engen, Eric M, and Jonathan Gruber. 2001. "Unemployment insurance and precautionary saving." Journal of monetary Economics, 47(3): 545-579.

Evans, William N, and Craig Garthwaite. 2014. "Giving Mom a Break: The Impact of Higher EITC Payments on Maternal Health." American Economic Journal: Economic Policy, 6: 2258-290.

Farber, Henry S, and Robert Valletta. 2011. "Extended Unemployment Insurance and Unemployment Duration in the Great Recession: The US Experience." manuscript June, 24 .

Feenberg, Daniel, and Elisabeth Coutts. 1993. "An introduction to the TAXSIM model." Journal of Policy Analysis and management, 12(1): 189-194.

Finkelstein, Amy, Neale Mahoney, and Matthew J. Notowidigdo. 2017. "What Does (Formal) Health Insurance Do, and For Whom?" National Bureau of Economic Research Working Paper 23718.

Finkelstein, Amy, Sarah Taubman, Bill Wright, Mira Bernstein, Jonathan Gruber, Joseph P Newhouse, Heidi Allen, Katherine Baicker, et al. 2012. "The Oregon Health Insurance Experiment: Evidence from the First Year*." The Quarterly Journal of Economics, 127(3): 1057-1106.

Garthwaite, Craig, Tal Gross, and Matthew J Notowidigdo. 2018. "Hospitals as insurers of last resort." American Economic Journal: Applied Economics, 10(1): 1-39.

Gruber, Jonathan. 1997. "The Consumption Smoothing Benefits of Unemployment Insurance." The American Economic Review, 87(1): pp. 192-205.

Gruber, Jonathan, and Brigitte C Madrian. 1997. "Employment separation and health insurance coverage." Journal of Public Economics, 66(3): 349-382.

Hagedorn, Marcus, Fatih Karahan, Iourii Manovskii, and Kurt Mitman. 2013. "Unemployment Benefits and Unemployment in the Great Recession: The Role of Macro Effects." National Bureau of Economic Research Working Paper 19499.

Hoynes, Hilary, Diane Whitmore Schanzenbach, and Douglas Almond. 2016. "Long-run impacts of childhood access to the safety net." The American Economic Review, 106(4): 903934. 
Hoynes, Hilary, Doug Miller, and David Simon. 2015. "Income, the earned income tax credit, and infant health." American Economic Journal: Economic Policy, 7(1): 172-211.

Hoynes, Hilary, Marianne Page, and Ann Huff Stevens. 2011. "Can targeted transfers improve birth outcomes?: Evidence from the introduction of the WIC program." Journal of Public Economics, 95(7): 813-827.

Hoynes, Hilary W, and Erzo FP Luttmer. 2011. "The insurance value of state tax-andtransfer programs." Journal of Public Economics, 95(11): 1466-1484.

Hsu, Joanne W, David A Matsa, and Brian T Melzer. 2018. "Unemployment insurance as a housing market stabilizer." American Economic Review, 108(1): 49-81.

Idler, Ellen L, and Yael Benyamini. 1997. "Self-rated health and mortality: a review of twenty-seven community studies." Journal of health and social behavior, 21-37.

Jacobson, Louis S, Robert J LaLonde, and Daniel G Sullivan. 1993. "Earnings Losses of Displaced Workers." The American Economic Review, 685-709.

Katz, Lawrence F, and Bruce D Meyer. 1990. "The Impact of the Potential Duration of Unemployment Benefits on the Duration of Unemployment." Journal of Public Economics, 41(1): $45-72$.

KFF. 2004. "Update on Individual Health Insurance." Kaiser Family Foundation/eHealthInsurance 7133-02.

KFF. 2010. "Survey of People Who Purchase Their Own Insurance." Kaiser Family Foundation 8077-R.

Kroft, Kory, and Matthew J Notowidigdo. 2016. "Should unemployment insurance vary with the unemployment rate? Theory and evidence." The Review of Economic Studies, 83(3): 1092-1124.

Kuhn, Andreas, Rafael Lalive, and Josef Zweimüller. 2009. "The public health costs of job loss." Journal of Health Economics, 28(6): 1099-1115.

Lalive, Rafael, Camille Landais, and Josef Zweimüller. 2015. "Market externalities of large unemployment insurance extension programs." The American Economic Review, 105(12): 3564-3596.

Lalive, Rafael, Jan Van Ours, and Josef Zweimüller. 2006. "How Changes in Financial Incentives Affect the Duration of Unemployment." The Review of Economic Studies, 73(4): 1009-1038.

LaLumia, Sara. 2013. "The EITC, Tax Refunds, and Unemployment Spells." American Economic Journal: Economic Policy, 5(2): 188-221.

Landais, Camille, Pascal Michaillat, and Emmanuel Saez. 2010. "Optimal Unemployment Insurance Over the Business Cycle." National Bureau of Economic Research. 
Lindahl, Mikael. 2005. "Estimating the effect of income on health and mortality using lottery prizes as an exogenous source of variation in income." Journal of Human Resources, 40(1): 144-168.

Lindo, Jason M. 2010. "Are children really inferior goods? Evidence from displacementdriven income shocks." Journal of Human Resources, 45(2): 301-327.

Lindo, Jason M. 2011. "Parental job loss and infant health." Journal of Health Economics, 30(5): $869-879$.

Marcus, Jan. 2013. "The effect of unemployment on the mental health of spouses-Evidence from plant closures in Germany." Journal of health economics, 32(3): 546-558.

Meer, Jonathan, Douglas L Miller, and Harvey S Rosen. 2003. "Exploring the health-wealth nexus." Journal of health economics, 22(5): 713-730.

Meyer, Bruce D. 1990. "Unemployment Insurance and Unemployment Spells." Econometrica, 58(4): $757-782$.

Moffitt, Robert A., and Mark Wilhelm. 1998. "Taxation and the Labor Supply: Decisions of the Affluent." National Bureau of Economic Research Working Paper 6621.

Nekoei, Arash, and Andrea Weber. 2017. "Does Extending Unemployment Benefits Improve Job Quality?" The American Economic Review, 107(2): 527-561.

Oreopoulos, Philip, Marianne Page, and Ann Huff Stevens. 2008. "The intergenerational effects of worker displacement." Journal of Labor Economics, 26(3): 455-000.

Rege, Mari, Kjetil Telle, and Mark Votruba. 2011. "Parental job loss and children's school performance." The Review of Economic Studies, 78(4): 1462-1489.

Rothstein, Jesse. 2011. "Unemployment Insurance and Job Search in the Great Recession." Brookings Papers on Economic Activity: Fall 2011, 143.

Ruhm, Christopher. 2000. "Are Recessions Good For Your Health?" The Quarterly Journal of Economics, 115(2): 617-650.

Schaller, Jessamyn, and Ann Huff Stevens. 2015. "Short-run effects of job loss on health conditions, health insurance, and health care utilization." Journal of health economics, 43: 190-203.

Schmieder, Johannes F, Till Von Wachter, and Stefan Bender. 2012. "The Effects of Extended Unemployment Insurance over the Business Cycle: Evidence from Regression Discontinuity Estimates over 20 Years." The Quarterly Journal of Economics, 127(2): 701-752.

Smith, Daniel L, and Jeffrey B Wenger. 2013. "State unemployment insurance trust solvency and benefit generosity." Journal of Policy Analysis and Management, 32(3): 536-553.

Snyder, Stephen E, and William N Evans. 2006. "The effect of income on mortality: evidence from the social security notch." The Review of Economics and Statistics, 88(3): 482-495. 
Stephens, Melvin. 2002. "Worker Displacement and the Added Worker Effect." Journal of Labor Economics, 20(3): 504-537.

Stevens, Ann Huff. 1997. "Persistent Effects of Job Displacement: The Importance of Multiple Job Losses." Journal of Labor Economics, 165-188.

Stevens, Ann Huff, and Jessamyn Schaller. 2011. "Short-run effects of parental job loss on children's academic achievement." Economics of Education Review, 30(2): 289-299.

Sullivan, Daniel, and Till Von Wachter. 2009. "Job displacement and mortality: An analysis using administrative data." The Quarterly Journal of Economics, 124(3): 1265-1306.

Yakusheva, Olga, Kandice A Kapinos, and Daniel Eisenberg. 2014. "Estimating Heterogeneous and Hierarchical Peer Effects on Body Weight Using Roommate Assignments as a Natural Experiment." Journal of Human Resources, 49(1): 234-261. 
Figure 1: Variation in UI Generosity

(a) Simulated Replacement Rates in 1993

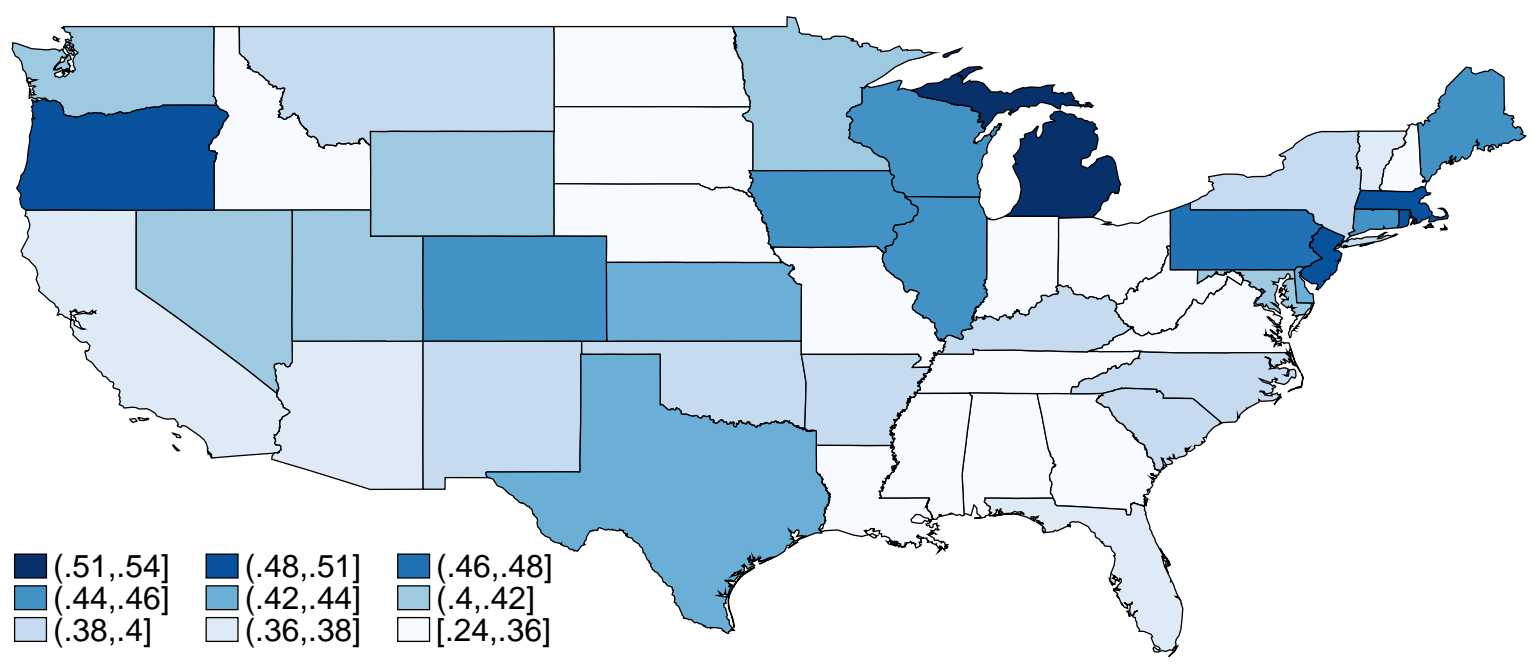

(b) Change in Simulated Replacement Rates - 1993-2015

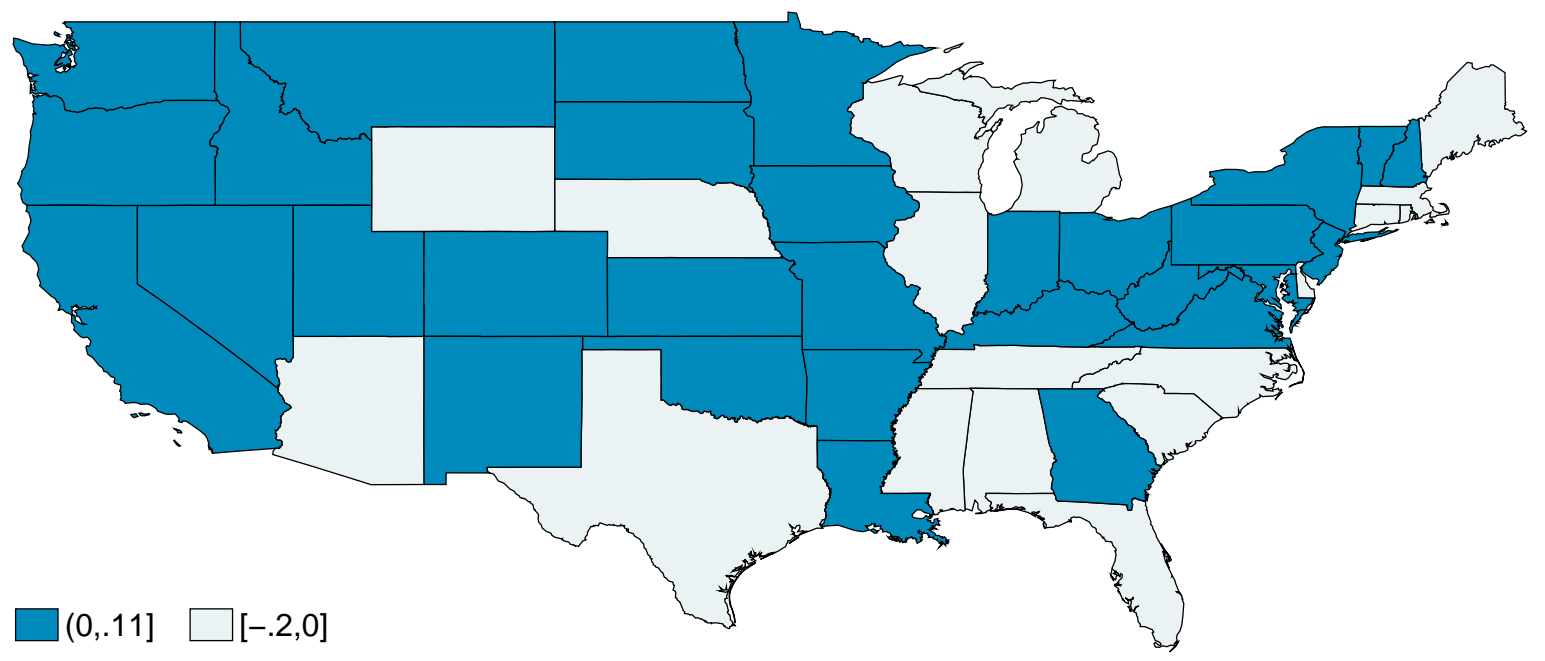

Notes: Data are from the 1996-2008 panels of the Survey of Income and Program Participation (SIPP). The sample includes all individuals that experience an involuntary job loss, observed in the month of job loss, who do not have missing demographics and who are ages 18-60. I then run this simulated sample through the UI generosity calculator, and then collapse the sample to have an average simulated replacement rate for each state and year. 
Figure 2: UI Generosity and Change in UI Benefits and Insurance Upon Job Loss

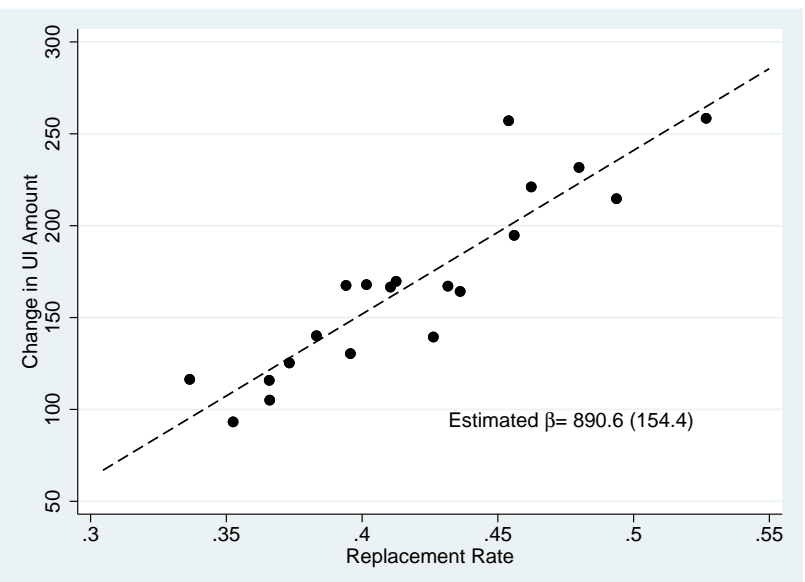

(a) Monthly UI Benefits $(\$ 2015)$

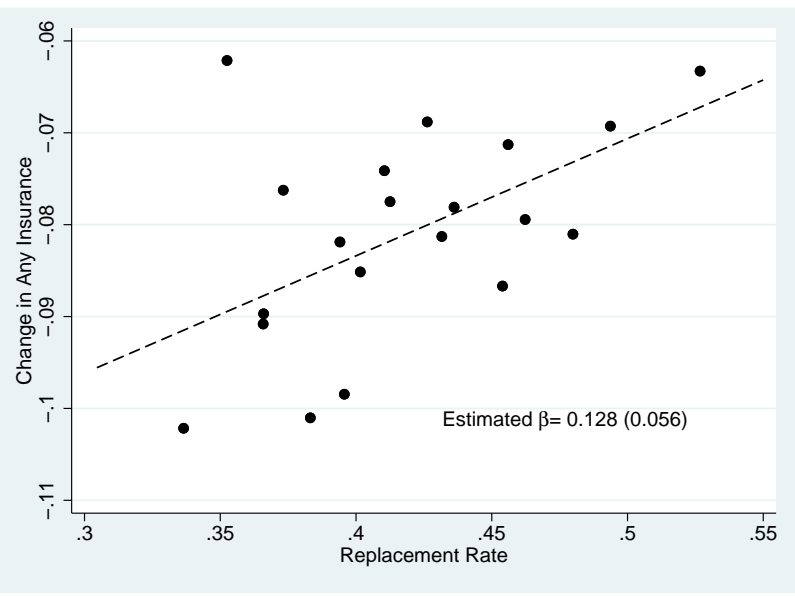

(b) Any Health Insurance Coverage

Notes: Data are from the 1996-2008 panels of the Survey of Income and Program Participation (SIPP). The sample includes all individuals that experience an involuntary job loss, observed in the month of job loss, who do not have missing demographics and who are ages 18-60. For each of these individuals, I calculate the change in UI benefits and insurance coverage between the 24 months after and the 12 months prior to job loss. I then estimate the relationship between this change and the simulated replacement rate the individual is eligible for. Last, I collapse the data into 20 equivalent bins, and I plot both these binned data and the estimated relationship (dashed line).

Figure 3: 1996-2013 Differences in UI Generosity and Change in UI Benefits and Insurance Upon Job Loss

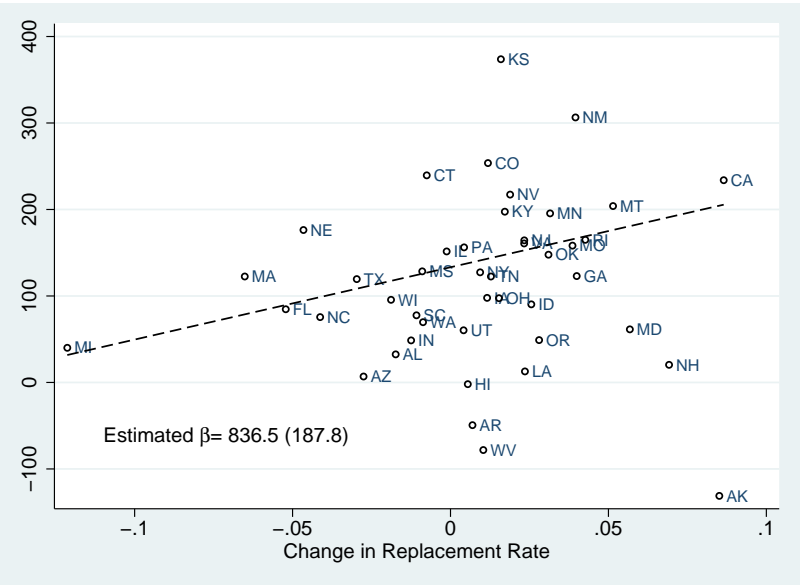

(a) Monthly UI Benefits $(\$ 2015)$

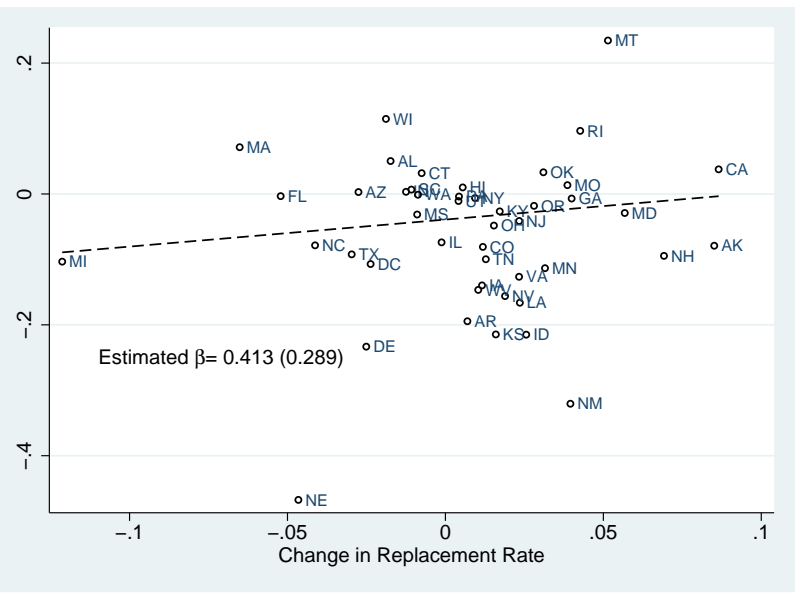

(b) Any Health Insurance Coverage

Notes: Data are from the 1996-2008 panels of the Survey of Income and Program Participation (SIPP). The sample includes all individuals that experience an involuntary job loss, observed in the month of job loss, who do not have missing demographics and who are ages 18-60. For each of these individuals, I calculate the change in UI benefits and insurance coverage between the 24 months after and the 12 months prior to job loss, as well as the simulated replacement rate the individual is eligible for. I then collapse the data at the state-year level, and for each state I calculate the 1996-2013 differences in UI generosity and change in UI and insurance upon job loss, plotted in the figures. 
Figure 4: Effect of UI Generosity on Monthly UI Benefits (\$2015) - "First Stage" - SIPP

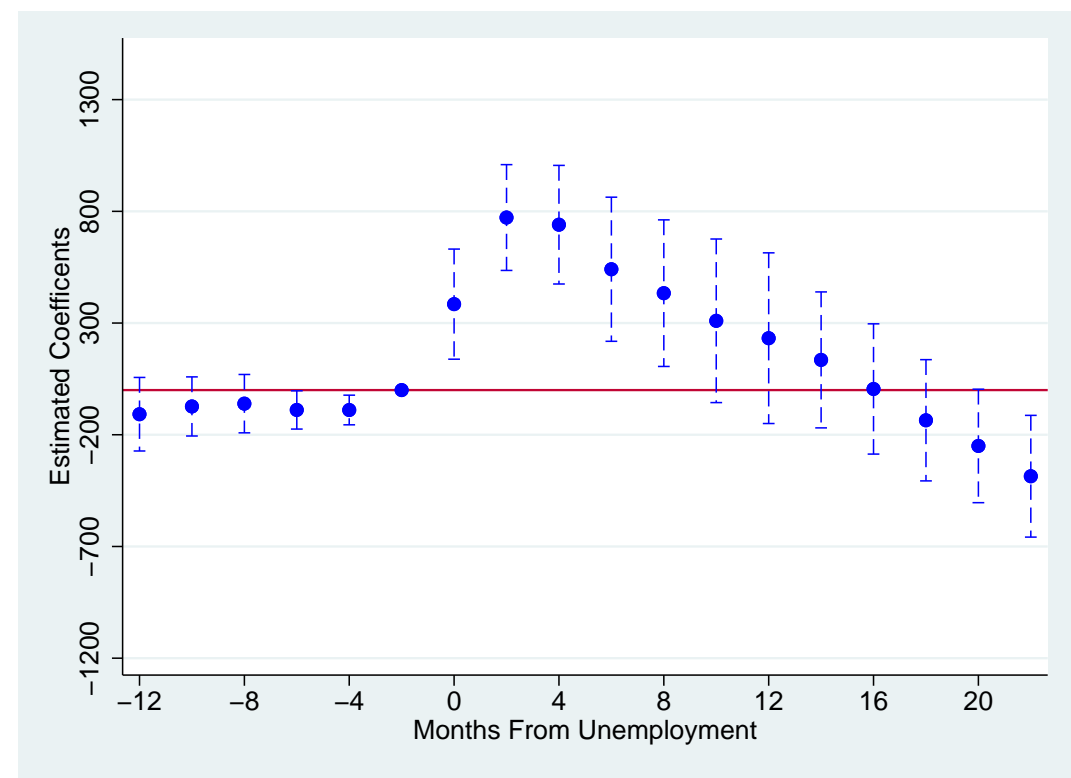

Notes: Data are from the 1996-2008 panels of the Survey of Income and Program Participation (SIPP). The sample includes all individuals that experience an involuntary job loss, 12 months prior to 24 months after the start of the spell, who do not have missing demographics and who are ages 18-60. The figures display coefficients and confidence intervals for the interactions between UI replacement rates and months relative to job loss. The regression includes individual fixed effects, flexible demographic controls, and cubic polynomials for the state unemployment rate and the state average annual wage. Moreover, the results include year-by-job loss, number of children-by-job loss, and state-by-job loss fixed effects, as well as state-specific linear time trends, and are weighted using the SIPP provided sample weights. Standard errors are clustered by state and shown in parentheses. 
Figure 5: Effect of UI Generosity on Health Insurance Coverage - SIPP

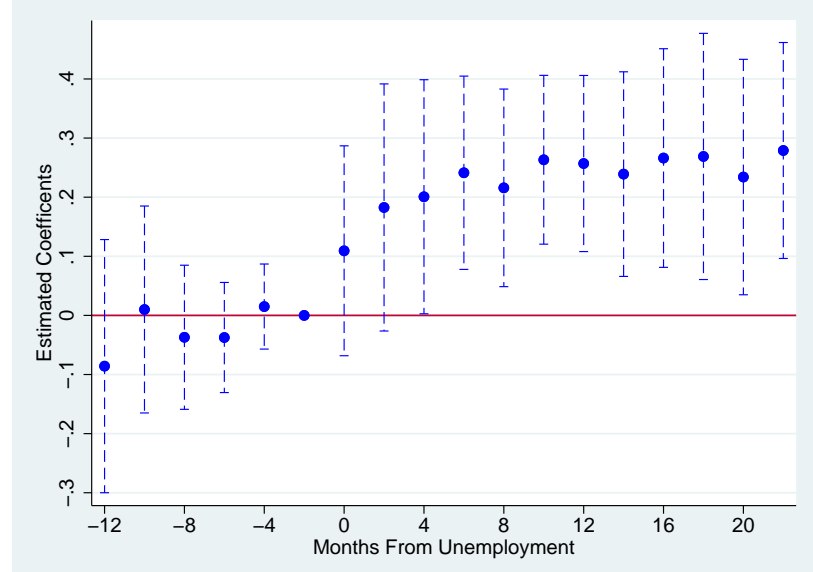

(a) Any

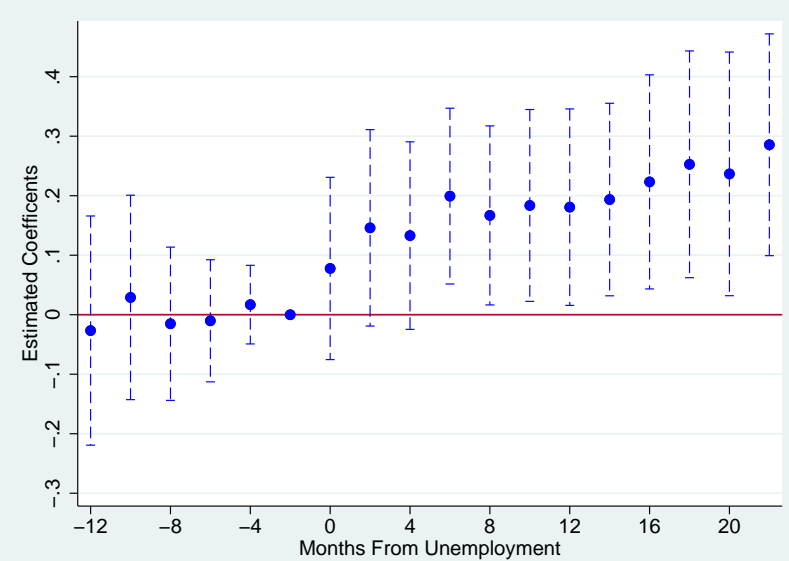

(b) Private

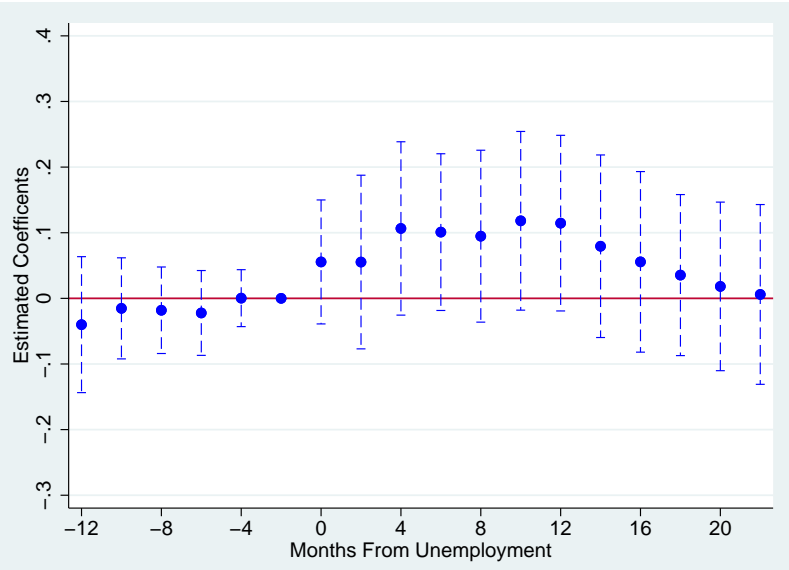

(c) Medicare/Medicaid

Notes: Data are from the 1996-2008 panels of the Survey of Income and Program Participation (SIPP). The sample includes all individuals that experience an involuntary job loss, 12 months prior to 24 months after the start of the spell, who do not have missing demographics and who are ages 18-60. The figures display coefficients and confidence intervals for the interactions between UI replacement rates and months relative to job loss. All regressions include individual fixed effects, flexible demographic controls, and cubic polynomials for the state unemployment rate and the state average annual wage. Moreover, the results include year-by-job loss, number of children-by-job loss, and state-by-job loss fixed effects, as well as state-specific linear time trends, and are weighted using the SIPP provided sample weights. Standard errors are clustered by state and shown in parentheses. 
Table 1: Sample Summary Statistics - BRFSS and SIPP

\begin{tabular}{|c|c|c|c|c|}
\hline & \multicolumn{2}{|c|}{ SIPP 1996-2013: Samples } & \multicolumn{2}{|c|}{ BRFSS 1993-2015: Sample } \\
\hline & Main & Calculator & Unemployed & Employed \\
\hline \multicolumn{5}{|l|}{ A: Demographics } \\
\hline$\overline{\text { Age }}$ & $\begin{array}{c}36.76 \\
(11.67)\end{array}$ & $\begin{array}{c}37.14 \\
(11.69)\end{array}$ & $\begin{array}{c}34.71 \\
(12.21)\end{array}$ & $\begin{array}{c}38.75 \\
(11.28)\end{array}$ \\
\hline Female & $\begin{array}{c}0.423 \\
(0.494)\end{array}$ & $\begin{array}{c}0.411 \\
(0.492)\end{array}$ & $\begin{array}{c}0.461 \\
(0.498)\end{array}$ & $\begin{array}{c}0.462 \\
(0.499)\end{array}$ \\
\hline Black & $\begin{array}{c}0.145 \\
(0.352)\end{array}$ & $\begin{array}{c}0.131 \\
(0.337)\end{array}$ & $\begin{array}{c}0.180 \\
(0.384)\end{array}$ & $\begin{array}{c}0.108 \\
(0.311)\end{array}$ \\
\hline College & $\begin{array}{c}0.175 \\
(0.380)\end{array}$ & $\begin{array}{c}0.177 \\
(0.382)\end{array}$ & $\begin{array}{c}0.181 \\
(0.385)\end{array}$ & $\begin{array}{c}0.353 \\
(0.478)\end{array}$ \\
\hline Married & $\begin{array}{c}0.467 \\
(0.499)\end{array}$ & $\begin{array}{c}0.478 \\
(0.500)\end{array}$ & $\begin{array}{c}0.360 \\
(0.480)\end{array}$ & $\begin{array}{c}0.598 \\
(0.490)\end{array}$ \\
\hline N. Children & $\begin{array}{c}0.875 \\
(1.128)\end{array}$ & $\begin{array}{c}0.850 \\
(1.115)\end{array}$ & $\begin{array}{c}0.966 \\
(1.175)\end{array}$ & $\begin{array}{c}0.953 \\
(1.127)\end{array}$ \\
\hline Annual Wage Prior To Job Loss (\$2015) & & $\begin{array}{c}32356.9 \\
(33230.3)\end{array}$ & & \\
\hline B: Outcomes & & & & \\
\hline Monthly UI Benefits (\$2015) & $\begin{array}{c}145.4 \\
(551.9)\end{array}$ & & & \\
\hline Health Insurance Coverage & $\begin{array}{c}0.634 \\
(0.482)\end{array}$ & & $\begin{array}{c}0.636 \\
(0.481)\end{array}$ & $\begin{array}{c}0.917 \\
(0.276)\end{array}$ \\
\hline Private Health Insurance & $\begin{array}{c}0.544 \\
(0.498)\end{array}$ & & & \\
\hline Medicare/Medicaid & $\begin{array}{c}0.101 \\
(0.302)\end{array}$ & & & \\
\hline Checkup Last Year & & & $\begin{array}{c}0.647 \\
(0.478)\end{array}$ & $\begin{array}{c}0.731 \\
(0.443)\end{array}$ \\
\hline Can Afford Doctor & & & $\begin{array}{c}0.649 \\
(0.477)\end{array}$ & $\begin{array}{c}0.877 \\
(0.328)\end{array}$ \\
\hline Breast Exam Last Year & & & $\begin{array}{c}0.633 \\
(0.482)\end{array}$ & $\begin{array}{c}0.742 \\
(0.438)\end{array}$ \\
\hline Good Health Status & & & $\begin{array}{c}0.856 \\
(0.351)\end{array}$ & $\begin{array}{c}0.944 \\
(0.229)\end{array}$ \\
\hline Physically Healthy & & & $\begin{array}{c}0.58 \\
(0.494)\end{array}$ & $\begin{array}{c}0.662 \\
(0.473)\end{array}$ \\
\hline Mentally Healthy & & & $\begin{array}{c}0.415 \\
(0.493)\end{array}$ & $\begin{array}{c}0.556 \\
(0.497)\end{array}$ \\
\hline High BMI & & & $\begin{array}{c}0.548 \\
(0.498)\end{array}$ & $\begin{array}{c}0.498 \\
(0.500)\end{array}$ \\
\hline Any Exercise & & & $\begin{array}{c}0.782 \\
(0.413)\end{array}$ & $\begin{array}{c}0.836 \\
(0.371)\end{array}$ \\
\hline Smoking Daily & & & $\begin{array}{c}0.273 \\
(0.445)\end{array}$ & $\begin{array}{c}0.145 \\
(0.352)\end{array}$ \\
\hline$\%$ Days Drinking & & & $\begin{array}{c}0.209 \\
(0.235)\end{array}$ & $\begin{array}{c}0.214 \\
(0.232)\end{array}$ \\
\hline \% Days Binge Drinking & & & $\begin{array}{l}0.0375 \\
(0.105)\end{array}$ & $\begin{array}{c}0.0240 \\
(0.0761)\end{array}$ \\
\hline Observations & 444,451 & 14,238 & 144,993 & $2,678,294$ \\
\hline
\end{tabular}

Notes: Data are from the 1996-2008 panels of the Survey of Income and Program Participation (SIPP) and the 1993-2015 Behavioral Risk Factor Surveillance System (BRFSS). The first column contains SIPP individuals that experience an involuntary job loss, observed monthly over a period of 12 months prior to 24 months after such loss. The second column contains SIPP individuals that experience an involuntary job loss, observed in the month of job loss. The third and fourth columns show statistics for the BRFFS samples of individuals who have been unemployed for less than a year and those who are currently working for wages, respectively. For all samples I exclude individuals with missing demographics and those older than 60 . All statistics are weighted using the sample weights provided in the two datasets. 
Table 2: Effect of State Economics Conditions on UI Generosity

\begin{tabular}{|c|c|c|c|c|c|c|c|}
\hline & $(1)$ & $(2)$ & $(3)$ & $(4)$ & $(5)$ & $(6)$ & $(7)$ \\
\hline Unemployment Rate (\%) & $\begin{array}{l}-0.102 \\
(0.161)\end{array}$ & $\begin{array}{l}-1.839 \\
(1.220)\end{array}$ & & & & & $\begin{array}{l}-1.904^{*} \\
(1.051)\end{array}$ \\
\hline Unemployment Rate ${ }^{2}$ & & $\begin{array}{c}0.221 \\
(0.143)\end{array}$ & & & & & $\begin{array}{c}0.237^{*} \\
(0.121)\end{array}$ \\
\hline Unemployment Rate ${ }^{3}$ & & $\begin{array}{c}-0.009 \\
(0.006)\end{array}$ & & & & & $\begin{array}{c}-0.009^{*} \\
(0.005)\end{array}$ \\
\hline Average Weekly Wage $(\$ 2015,1000$ s) & & & $\begin{array}{c}1.761 \\
(3.592)\end{array}$ & $\begin{array}{c}36.641 \\
(78.511)\end{array}$ & & & $\begin{array}{c}67.535 \\
(79.573)\end{array}$ \\
\hline Average Weekly Wage ${ }^{2}$ & & & & $\begin{array}{l}-19.027 \\
(85.749)\end{array}$ & & & $\begin{array}{l}-54.077 \\
(87.080)\end{array}$ \\
\hline Average Weekly Wage ${ }^{3}$ & & & & $\begin{array}{c}0.042 \\
(30.262)\end{array}$ & & & $\begin{array}{c}12.559 \\
(30.911)\end{array}$ \\
\hline Employment Rate (\%) & & & & & $\begin{array}{c}0.220 \\
(0.169)\end{array}$ & $\begin{array}{l}-7.809 \\
(9.805)\end{array}$ & $\begin{array}{c}-14.956 \\
(10.470)\end{array}$ \\
\hline Employment Rate ${ }^{2}$ & & & & & & $\begin{array}{c}0.163 \\
(0.211)\end{array}$ & $\begin{array}{c}0.321 \\
(0.224)\end{array}$ \\
\hline Employment Rate ${ }^{3}$ & & & & & & $\begin{array}{c}-0.001 \\
(0.002) \\
\end{array}$ & $\begin{array}{c}-0.002 \\
(0.002)\end{array}$ \\
\hline Mean R-rate & 41.08 & 41.08 & 41.08 & 41.08 & 41.08 & 41.08 & 41.08 \\
\hline R-squared & 0.926 & 0.927 & 0.926 & 0.927 & 0.926 & 0.926 & 0.928 \\
\hline Observations & 1173 & 1173 & 1173 & 1173 & 1173 & 1173 & 1173 \\
\hline
\end{tabular}

Notes: UI replacement rates are calculated using the 1996-2008 panels of the Survey of Income and Program Participation (SIPP). The state unemployment rate and employment level comes from the BLS, the state population is from SEER, average weekly wages are calculated with the CPS, and net reserves are from ETA. All regressions include state and year fixed effects, as well as state-specific linear time trends. All statistics are weighted using state population. Standard errors are clustered by state and shown in parentheses. ${ }^{*} \mathrm{p}<0.10$, $* * \mathrm{p}<0.05, * * * \mathrm{p}<0.01$.

Table 3: Effect of UI Generosity on Safety Net Programs

\begin{tabular}{|c|c|c|c|c|c|c|}
\hline & Min Wage & State EITC & Max AFDC & Medicaid Thresh & Welfare Reform & Max UI \\
\hline \multicolumn{7}{|c|}{ A: State Program Parameters } \\
\hline State R-rate & $\begin{array}{c}0.008 \\
(0.017)\end{array}$ & $\begin{array}{c}0.012 \\
(0.085)\end{array}$ & $\begin{array}{l}5.503^{* *} \\
(2.305)\end{array}$ & $\begin{array}{c}2.947 \\
(4.250)\end{array}$ & $\begin{array}{c}0.382 \\
(0.403)\end{array}$ & $\begin{array}{c}10.895^{* * *} \\
(3.311)\end{array}$ \\
\hline Mean Y & 0.07 & 0.05 & 6.22 & 2.25 & 0.75 & 4.43 \\
\hline Mean R-rate & 0.41 & 0.41 & 0.41 & 0.41 & 0.41 & 0.41 \\
\hline Observations & 1173 & 1173 & 1173 & 1122 & 1173 & 1173 \\
\hline & SNAP & EITC & ADFC & Medicaid & SS & UI \\
\hline \multicolumn{7}{|c|}{ B: State Program Spending/Population } \\
\hline State R-rate & $\begin{array}{l}-11.503 \\
(12.012)\end{array}$ & $\begin{array}{c}-8.725^{* * *} \\
(2.395)\end{array}$ & $\begin{array}{c}3.138 \\
(4.180)\end{array}$ & $\begin{array}{l}-46.779 \\
(63.535)\end{array}$ & $\begin{array}{c}21.587 \\
(35.815)\end{array}$ & $\begin{array}{l}31.086^{* *} \\
(13.487)\end{array}$ \\
\hline Mean Y & 14.778 & 16.493 & 8.565 & 118.159 & 231.494 & 13.316 \\
\hline Mean R-rate & 0.41 & 0.41 & 0.41 & 0.41 & 0.41 & 0.41 \\
\hline Observations & 1173 & 1173 & 1173 & 1173 & 1173 & 1173 \\
\hline
\end{tabular}

Notes: UI replacement rates are calculated using the 1996-2008 panels of the Survey of Income and Program Participation (SIPP). State EITC generosity is from the Tax Policy Center, data on welfare reform come from Bitler and Hoynes (2010), and state Medicaid/SCHIP income eligibility thresholds, minimum wages, AFDC/TANF generosity, and gross state product (GSP) come from the University of Kentucky Center for Poverty Research. State spending on SNAP, EITC, AFDC/TANF, Medicaid, and SSDI comes from the Bureau of Economic Analysis Regional Economic Accounts, and UI spending comes from ETA. All regressions include flexible controls for state economic conditions, as well as year and state fixed effects and state-specific linear time trends. All statistics are weighted using state population, obtained from SEER. Standard errors are clustered by state and shown in parentheses. ${ }^{*} \mathrm{p}<0.10,{ }^{* *} \mathrm{p}<0.05,{ }^{* * *} \mathrm{p}<0.01$. 
Table 4: Effect of UI Generosity on UI Benefits and Insurance Coverage - SIPP

\begin{tabular}{lccccc}
\hline \hline & Monthly UI & & \multicolumn{3}{c}{ Health Insurance } \\
\cline { 2 - 2 } \cline { 5 - 6 } & Benefit & & Any & Private & Public \\
\hline R-rate ${ }^{*}$ Loss & $448.630^{* * *}$ & & $0.208^{* * *}$ & $0.148^{* *}$ & 0.084 \\
& $(143.341)$ & & $(0.068)$ & $(0.072)$ & $(0.053)$ \\
\hline Mean Y & 144.79 & & 0.64 & 0.55 & 0.10 \\
Observations & 444451 & & 444451 & 444388 & 444331 \\
\hline \hline
\end{tabular}

Notes: Data are from the 1996-2008 panels of the Survey of Income and Program Participation (SIPP). The sample includes all individuals that experience an involuntary job loss, 12 months prior to 24 months after the start of the spell, who do not have missing demographics and who are ages 18-60. All regressions include individual fixed effects, flexible demographic controls, and cubic polynomials for the state unemployment rate and the state average annual wage. Moreover, the results include year-by-job loss, number of children-byjob loss, and state-by-job loss fixed effects, as well as state-specific linear time trends, and are weighted using the SIPP provided sample weights. Standard errors are clustered by state and shown in parentheses. ${ }^{*} \mathrm{p}<0.10,{ }^{* *} \mathrm{p}<0.05,{ }^{* * *} \mathrm{p}<0.01$. 


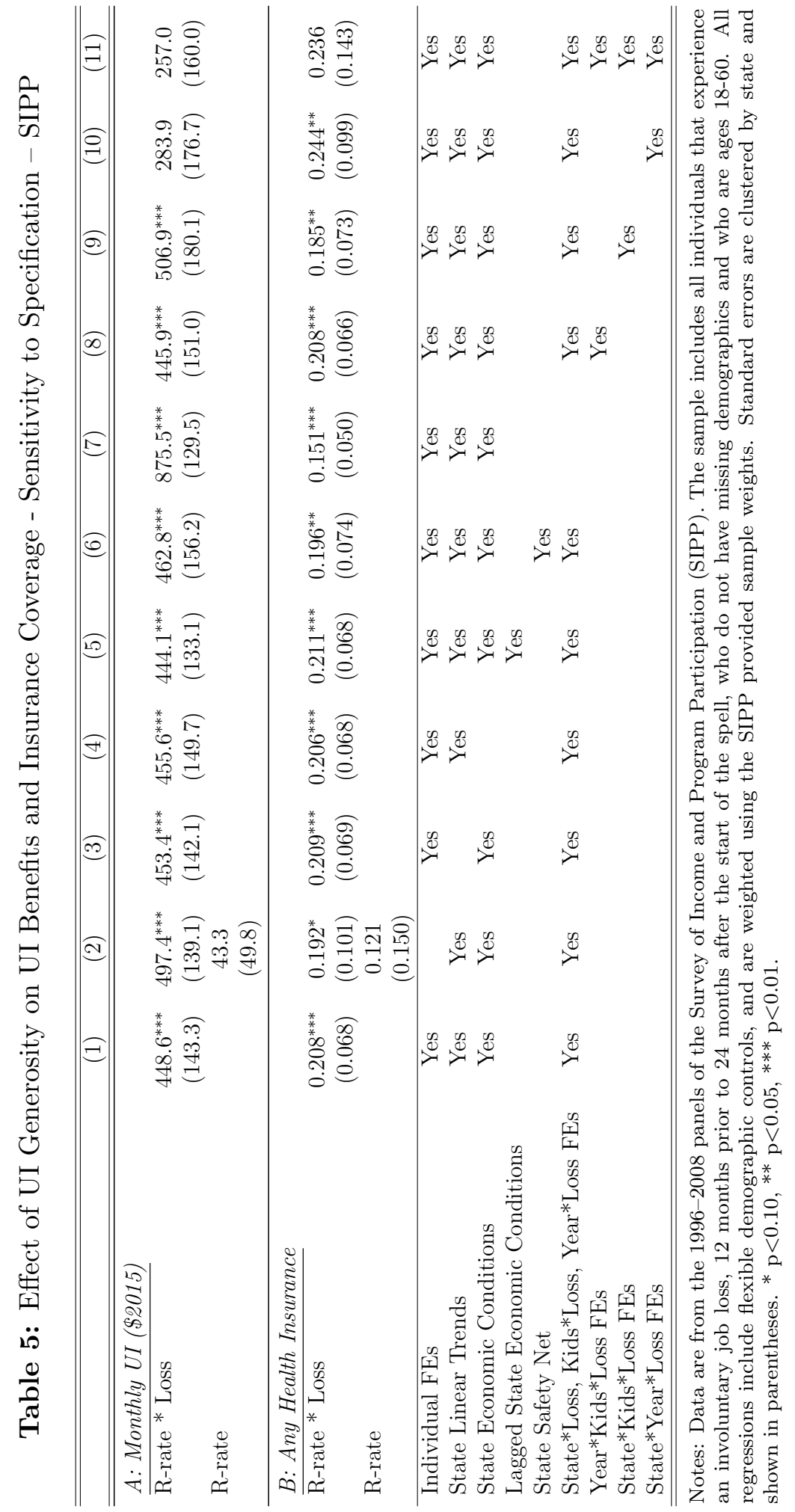


Table 6: Placebo Effect of UI Generosity on UI Benefits and Insurance Coverage - Placebo

\begin{tabular}{|c|c|c|c|c|c|c|}
\hline & \multicolumn{2}{|c|}{ Involuntary Job Loss } & \multicolumn{2}{|c|}{ Quit For Another Job } & \multicolumn{2}{|c|}{ Other Separations } \\
\hline & Monthly & Any & Monthly & Any & Monthly & Any \\
\hline & UI & Insurance & UI & Insurance & UI & Insurance \\
\hline R-rate ${ }^{*}$ Loss/Separation & $\begin{array}{c}448.630^{* * *} \\
(143.341)\end{array}$ & $\begin{array}{c}0.208^{* * *} \\
(0.068)\end{array}$ & $\begin{array}{c}-11.976 \\
(0.072)\end{array}$ & $\begin{array}{c}-0.016 \\
(0.053)\end{array}$ & $\begin{array}{c}13.975 \\
(30.075)\end{array}$ & $\begin{array}{c}0.073 \\
(0.055)\end{array}$ \\
\hline Mean Y & 144.79 & 0.64 & 18.69 & 0.75 & 29.46 & 0.73 \\
\hline Observations & 444451 & 444451 & 386410 & 386410 & 1375489 & 1375489 \\
\hline
\end{tabular}

Notes: Data are from the 1996-2008 panels of the Survey of Income and Program Participation (SIPP). The sample includes all individuals that experience a job separation, 12 months prior to 24 months after the start of the spell, who do not have missing demographics and who are ages 18-60. In the first two columns I include those that experience a job separation because of involuntary job loss, in the next two columns I include individuals who quit to get another job, and in the final two columns I include all those that experience a job loss that is not involuntary job loss nor quitting for another job. All regressions include individual fixed effects, flexible demographic controls, and cubic polynomials for the state unemployment rate and the state average annual wage. Moreover, the results include year-by-job loss, number of children-by-job loss, and state-by-job loss fixed effects, as well as state-specific linear time trends, and are weighted using the SIPP provided sample weights. Standard errors are clustered by state and shown in parentheses. ${ }^{*} \mathrm{p}<0.10,{ }^{* *} \mathrm{p}<0.05,{ }^{* * *} \mathrm{p}<0.01$.

Table 7: Effect of UI Generosity on Health Insurance and Utilization - BRFSS

\begin{tabular}{|c|c|c|c|c|c|}
\hline & \multirow[b]{2}{*}{ Health Insurance } & \multirow[b]{2}{*}{ Checkup } & \multirow[b]{2}{*}{ Afford Doctor } & \multicolumn{2}{|c|}{ Breast Exam } \\
\hline & & & & Last Year & Ever \\
\hline \multicolumn{6}{|c|}{ A: State, Year Fixed Effects: Unemployed } \\
\hline R-rate & $\begin{array}{l}0.327^{* *} \\
(0.123)\end{array}$ & $\begin{array}{c}0.344^{* * *} \\
(0.104)\end{array}$ & $\begin{array}{c}0.078 \\
(0.087)\end{array}$ & $\begin{array}{l}0.526^{* *} \\
(0.227)\end{array}$ & $\begin{array}{c}0.064 \\
(0.114)\end{array}$ \\
\hline Mean Y & 0.54 & 0.59 & 0.70 & 0.69 & 0.84 \\
\hline Observations & 144066 & 117712 & 140273 & 40358 & 46216 \\
\hline \multicolumn{6}{|l|}{ B: Triple Differences } \\
\hline$\overline{\text { R-rate } * \text { Unemployed }}$ & $\begin{array}{c}0.277^{* * *} \\
(0.075)\end{array}$ & $\begin{array}{c}0.271^{* * *} \\
(0.059)\end{array}$ & $\begin{array}{c}0.029 \\
(0.046)\end{array}$ & $\begin{array}{c}0.609^{* * *} \\
(0.177)\end{array}$ & $\begin{array}{c}0.064 \\
(0.075)\end{array}$ \\
\hline R-rate & $\begin{array}{c}0.076^{* * *} \\
(0.026)\end{array}$ & $\begin{array}{c}0.025 \\
(0.062)\end{array}$ & $\begin{array}{c}0.055 \\
(0.036)\end{array}$ & $\begin{array}{l}0.122^{* *} \\
(0.054)\end{array}$ & $\begin{array}{l}-0.070 \\
(0.048)\end{array}$ \\
\hline Mean Y & 0.85 & 0.65 & 0.87 & 0.75 & 0.91 \\
\hline Observations & 2817386 & 2316660 & 2724142 & 895227 & 961936 \\
\hline \multicolumn{6}{|c|}{ C: Triple Differences, State ${ }^{*}$ Year $^{*}$ Kids FEs } \\
\hline R-rate $*$ Unemployed & $\begin{array}{c}0.272^{* * *} \\
(0.074)\end{array}$ & $\begin{array}{c}0.244^{* * *} \\
(0.060)\end{array}$ & $\begin{array}{c}0.030 \\
(0.047)\end{array}$ & $\begin{array}{c}0.590^{* * *} \\
(0.185)\end{array}$ & $\begin{array}{c}0.047 \\
(0.072)\end{array}$ \\
\hline Mean Y & 0.85 & 0.65 & 0.87 & 0.75 & 0.91 \\
\hline Observations & 2817386 & 2316650 & 2724135 & 895139 & 961847 \\
\hline
\end{tabular}

Notes: Data are from the 1993-2015 Behavioral Risk Factor Surveillance System (BRFSS). The sample includes individuals who have been unemployed for less than a year or who are currently working for wages. I exclude individuals with missing demographics and those older than 60 . All regressions include flexible demographic controls, as well as cubic polynomials for the state unemployment rate and the state average annual wage. Moreover, the results in Panel A include year and state fixed effects and state-specific linear time trends, the results in Panels B and C contain additional state-by-job loss, year-by-job loss, and children-by-job loss fixed effects, and Panel $\mathrm{C}$ also includes state-by-year-by-number of children fixed effects. The results are weighted using the BRFSS provided sample weights. Standard errors are clustered by state and shown in parentheses. ${ }^{*} \mathrm{p}<0.10,{ }^{* *} \mathrm{p}<0.05,{ }^{* * *} \mathrm{p}<0.01$. 
Table 8: Effect of UI Generosity on Self-Reported Health - BRFSS

\begin{tabular}{|c|c|c|c|c|c|c|c|}
\hline & \multicolumn{3}{|c|}{ General Health } & \multicolumn{2}{|c|}{ Physically Healthy } & \multicolumn{2}{|c|}{ Mentally Healthy } \\
\hline & Continuous & Good & Excellent & Days & Always & Days & Always \\
\hline \multicolumn{8}{|c|}{ A: State, Year Fixed Effects: Unemployed } \\
\hline R-rate & $\begin{array}{c}0.237 \\
(0.185)\end{array}$ & $\begin{array}{c}0.032 \\
(0.080)\end{array}$ & $\begin{array}{c}0.122^{*} \\
(0.067)\end{array}$ & $\begin{array}{c}0.536 \\
(1.219)\end{array}$ & $\begin{array}{l}-0.134 \\
(0.106)\end{array}$ & $\begin{array}{l}-1.805 \\
(2.751)\end{array}$ & $\begin{array}{l}-0.198 \\
(0.165)\end{array}$ \\
\hline Mean Y & 3.47 & 0.83 & 0.18 & 26.32 & 0.63 & 24.32 & 0.53 \\
\hline Observations & 144532 & 144532 & 144532 & 139220 & 139220 & 139076 & 139076 \\
\hline \multicolumn{8}{|l|}{ B: Triple Differences } \\
\hline$\overline{\text { R-rate } * \text { Unemployed }}$ & $\begin{array}{c}0.191^{*} \\
(0.106)\end{array}$ & $\begin{array}{c}0.043 \\
(0.042)\end{array}$ & $\begin{array}{c}0.081^{*} \\
(0.046)\end{array}$ & $\begin{array}{l}2.189^{* *} \\
(0.892)\end{array}$ & $\begin{array}{l}-0.023 \\
(0.057)\end{array}$ & $\begin{array}{c}0.048 \\
(1.276)\end{array}$ & $\begin{array}{c}-0.130 \\
(0.095)\end{array}$ \\
\hline R-rate & $\begin{array}{c}0.064 \\
(0.051)\end{array}$ & $\begin{array}{c}0.016 \\
(0.010)\end{array}$ & $\begin{array}{l}0.054^{* *} \\
(0.022)\end{array}$ & $\begin{array}{c}0.244 \\
(0.284)\end{array}$ & $\begin{array}{l}-0.043 \\
(0.044)\end{array}$ & $\begin{array}{l}-0.726 \\
(0.649)\end{array}$ & $\begin{array}{l}-0.045 \\
(0.045)\end{array}$ \\
\hline Mean Y & 3.76 & 0.91 & 0.25 & 27.89 & 0.69 & 26.91 & 0.65 \\
\hline Observations & 2818225 & 2818225 & 2818225 & 2731728 & 2731728 & 2727278 & 2727278 \\
\hline \multicolumn{8}{|c|}{ C: Triple Differences, State ${ }^{*}$ Year $^{*}$ Kids FE } \\
\hline R-rate ${ }^{*}$ Unemployed & $\begin{array}{l}0.236^{* *} \\
(0.107)\end{array}$ & $\begin{array}{c}0.057 \\
(0.044)\end{array}$ & $\begin{array}{l}0.085^{*} \\
(0.045)\end{array}$ & $\begin{array}{l}2.245^{* *} \\
(0.875)\end{array}$ & $\begin{array}{l}-0.029 \\
(0.050)\end{array}$ & $\begin{array}{c}0.084 \\
(1.294)\end{array}$ & $\begin{array}{l}-0.130 \\
(0.091)\end{array}$ \\
\hline Mean Y & 3.76 & 0.91 & 0.25 & 27.89 & 0.69 & 26.91 & 0.65 \\
\hline Observations & 2818225 & 2818225 & 2818225 & 2731724 & 2731724 & 2727274 & 2727274 \\
\hline
\end{tabular}

Notes: Data are from the 1993-2015 Behavioral Risk Factor Surveillance System (BRFSS). The sample includes individuals who have been unemployed for less than a year or who are currently working for wages. I exclude individuals with missing demographics and those older than 60 . All regressions include flexible demographic controls, as well as cubic polynomials for the state unemployment rate and the state average annual wage. Moreover, the results in Panel A include year and state fixed effects and statespecific linear time trends, the results in Panels B and C contain additional state-by-job loss, year-by-job loss, and children-by-job loss fixed effects, and Panel C also includes state-by-year-by-number of children fixed effects. The results are weighted using the BRFSS provided sample weights. Standard errors are clustered by state and shown in parentheses. ${ }^{*} \mathrm{p}<0.10,{ }^{* *} \mathrm{p}<0.05, * * * \mathrm{p}<0.01$. 
Table 9: Heterogeneity of Effects by Economic Conditions - BRFSS

\begin{tabular}{|c|c|c|c|c|c|c|}
\hline & \multirow{2}{*}{$\frac{\text { Insurance }}{\text { Coverage }}$} & \multicolumn{2}{|c|}{ Utilization } & \multicolumn{3}{|c|}{ General Health Status } \\
\hline & & Checkup & Afford Doctor & Continuous & Good & Excellent \\
\hline \multicolumn{7}{|c|}{ A: State,Year Fixed Effects: Unemployed } \\
\hline R-rate ${ }^{*} 0-5.5 \%$ UR & $\begin{array}{l}0.272^{* *} \\
(0.111)\end{array}$ & $\begin{array}{l}0.300^{* *} \\
(0.126)\end{array}$ & $\begin{array}{c}0.005 \\
(0.098)\end{array}$ & $\begin{array}{c}-0.003 \\
(0.234)\end{array}$ & $\begin{array}{c}-0.096 \\
(0.098)\end{array}$ & $\begin{array}{c}0.067 \\
(0.081)\end{array}$ \\
\hline R-rate $* 5.5+\%$ UR & $\begin{array}{c}0.365^{* * *} \\
(0.136)\end{array}$ & $\begin{array}{c}0.375^{* * *} \\
(0.101)\end{array}$ & $\begin{array}{c}0.126 \\
(0.097)\end{array}$ & $\begin{array}{l}0.406^{* *} \\
(0.186)\end{array}$ & $\begin{array}{c}0.122 \\
(0.078)\end{array}$ & $\begin{array}{l}0.159^{* *} \\
(0.070)\end{array}$ \\
\hline P-value UR Low $=$ High & 0.259 & 0.411 & 0.167 & 0.001 & 0.000 & 0.122 \\
\hline Observations & 144066 & 117712 & 140273 & 144532 & 144532 & 144532 \\
\hline \multicolumn{7}{|c|}{ B: Triple Differences, State* Year ${ }^{*}$ Kids FEs } \\
\hline R-rate * $0-5.5 \%$ UR * Unemployed & $\begin{array}{c}0.084 \\
(0.092)\end{array}$ & $\begin{array}{c}0.145 \\
(0.096)\end{array}$ & $\begin{array}{c}-0.138^{* *} \\
(0.068)\end{array}$ & $\begin{array}{c}0.012 \\
(0.140)\end{array}$ & $\begin{array}{c}-0.100 \\
(0.071)\end{array}$ & $\begin{array}{c}0.060 \\
(0.054)\end{array}$ \\
\hline R-rate $* 5.5+\%$ UR $*$ Unemployed & $\begin{array}{c}0.342^{* * *} \\
(0.077)\end{array}$ & $\begin{array}{c}0.294^{* * *} \\
(0.063)\end{array}$ & $\begin{array}{l}0.111^{* *} \\
(0.049)\end{array}$ & $\begin{array}{l}0.325^{* *} \\
(0.132)\end{array}$ & $\begin{array}{c}0.128^{* * *} \\
(0.046)\end{array}$ & $\begin{array}{l}0.096^{*} \\
(0.057)\end{array}$ \\
\hline P-value UR Low $=$ High & 0.005 & 0.136 & 0.006 & 0.042 & 0.001 & 0.581 \\
\hline Observations & 2817386 & 2316650 & 2724135 & 2818225 & 2818225 & 2818225 \\
\hline
\end{tabular}

Notes: Data are from the 1993-2015 Behavioral Risk Factor Surveillance System (BRFSS). The sample includes individuals who have been unemployed for less than a year or who are currently working for wages. I exclude individuals with missing demographics and those older than 60. All regressions include flexible demographic controls, as well as cubic polynomials for the state unemployment rate and the state average annual wage. Moreover, the results in Panel A include year and state fixed effects and state-specific linear time trends, while the regressions in Panel B include state-by-job loss, year-by-job loss, children-by-job loss, and state-by-year-by-number of children fixed effects. The results are weighted using the BRFSS provided sample weights. Standard errors are clustered by state and shown in parentheses. ${ }^{*} \mathrm{p}<0.10,{ }^{* *} \mathrm{p}<0.05,{ }^{* * *} \mathrm{p}<0.01$. 
Table 10: Effect of UI Generosity on Sample Characteristics - BRFSS and SIPP

\begin{tabular}{|c|c|c|c|c|c|c|c|c|}
\hline & \multirow{2}{*}{$\begin{array}{l}\text { Number of } \\
\text { Job Losers }\end{array}$} & \multicolumn{7}{|c|}{ Demographics } \\
\hline & & Female & Married & Age & Less HS & College & White & Black \\
\hline \multicolumn{9}{|c|}{ A: Unemployed, BRFSS } \\
\hline R-rate & $\begin{array}{c}-10352.1 \\
(63616.1)\end{array}$ & $\begin{array}{c}-0.185^{* * *} \\
(0.066)\end{array}$ & $\begin{array}{l}-0.062 \\
(0.144)\end{array}$ & $\begin{array}{l}-0.784 \\
(2.749)\end{array}$ & $\begin{array}{l}-0.283^{*} \\
(0.148)\end{array}$ & $\begin{array}{l}-0.017 \\
(0.093)\end{array}$ & $\begin{array}{c}0.174 \\
(0.142)\end{array}$ & $\begin{array}{c}0.128 \\
(0.123)\end{array}$ \\
\hline Mean Y & 22828.8 & 0.463 & 0.363 & 34.548 & 0.183 & 0.179 & 0.572 & 0.178 \\
\hline Observations & 5719 & 144993 & 144993 & 144993 & 144993 & 144993 & 144993 & 144993 \\
\hline \multicolumn{9}{|c|}{ B: Employed, BRFSS } \\
\hline R-rate & $\begin{array}{l}-338671.5 \\
(778345.1)\end{array}$ & $\begin{array}{l}-0.040 \\
(0.049)\end{array}$ & $\begin{array}{c}0.085 \\
(0.084)\end{array}$ & $\begin{array}{c}2.228 \\
(2.850)\end{array}$ & $\begin{array}{l}-0.128^{*} \\
(0.066)\end{array}$ & $\begin{array}{l}-0.010 \\
(0.074)\end{array}$ & $\begin{array}{c}0.129 \\
(0.096)\end{array}$ & $\begin{array}{l}-0.030 \\
(0.042)\end{array}$ \\
\hline Mean Y & 257030.4 & 0.462 & 0.601 & 38.518 & 0.084 & 0.347 & 0.711 & 0.107 \\
\hline Observations & 5845 & 2678294 & 2678294 & 2678294 & 2678294 & 2678294 & 2678294 & 2678294 \\
\hline \multicolumn{9}{|c|}{ C: Job Losers, SIPP } \\
\hline R-rate & $\begin{array}{c}7922.0 \\
(39624.0)\end{array}$ & $\begin{array}{l}-0.219 \\
(0.185)\end{array}$ & $\begin{array}{c}0.205 \\
(0.187)\end{array}$ & $\begin{array}{c}10.508^{* *} \\
(4.008)\end{array}$ & $\begin{array}{c}0.072 \\
(0.244)\end{array}$ & $\begin{array}{c}0.095 \\
(0.120)\end{array}$ & $\begin{array}{l}-0.144 \\
(0.162)\end{array}$ & $\begin{array}{c}0.132 \\
(0.130)\end{array}$ \\
\hline Mean Y & 15815.2 & 0.421 & 0.451 & 36.128 & 0.146 & 0.169 & 0.776 & 0.144 \\
\hline Observations & 2939 & 17112 & 17112 & 17112 & 17112 & 17112 & 17112 & 17112 \\
\hline
\end{tabular}

Notes: Data are from the 1993-2015 Behavioral Risk Factor Surveillance System (BRFSS) and the 1996-2008 panels of the Survey of Income and Program Participation (SIPP). The BRFSS sample includes individuals who have been unemployed for less than a year or who are currently working for wages, and the SIPP sample includes all individuals that experience a job separation, observed at the start of the spell. From both samples I exclude individuals with missing demographics and those older than 60 . The data is collapsed at the state, year and number of children level when analyzing sample size in column (1), while all other results are estimated at the individual level. All regressions include cubic polynomials for the state unemployment rate and the state average annual wage, year and state fixed effects and state-specific linear time trends. The results are weighted using the provided sample weights. Standard errors are clustered by state and shown in parentheses. ${ }^{*} \mathrm{p}<0.10$, $* * \mathrm{p}<0.05, * * * \mathrm{p}<0.01$. 


\section{A Further Results}

Table A.1: Effects of UI Generosity on UI Benefits and Insurance Coverage Sensitivity to Dropping 2008-2010 - SIPP

\begin{tabular}{|c|c|c|c|c|c|c|}
\hline & \multicolumn{2}{|c|}{ Baseline Sample } & \multicolumn{2}{|c|}{ Drop 2008-2010 Observations } & \multicolumn{2}{|c|}{ Drop 2008-2010 Job Losers } \\
\hline & Monthly & Any & Monthly & Any & Monthly & Any \\
\hline & UI & Insurance & UI & Insurance & UI & Insurance \\
\hline \multirow[t]{2}{*}{ R-rate * Loss } & $448.630^{* * *}$ & $0.208^{* * *}$ & $466.203^{* *}$ & $0.225^{* * *}$ & $508.145^{* * *}$ & $0.197^{* * *}$ \\
\hline & $(143.341)$ & $(0.068)$ & $(190.807)$ & $(0.069)$ & $(177.452)$ & $(0.067)$ \\
\hline Mean Y & 144.79 & 0.64 & 119.30 & 0.65 & 112.78 & 0.66 \\
\hline Observations & 444451 & 444451 & 331733 & 331733 & 309010 & 309010 \\
\hline
\end{tabular}

Notes: Data are from the 1996-2008 panels of the Survey of Income and Program Participation (SIPP). The sample includes all individuals that experience an involuntary job loss, 12 months prior to 24 months after the start of the spell, who do not have missing demographics and who are ages 18-60. The first two columns contains the baseline results. In columns (3) and (4) I drop observations in years 2008-2010, while in the last two columns I drop those individuals who lose their job in 2008-2010. All regressions include individual fixed effects, flexible demographic controls, and cubic polynomials for the state unemployment rate and the state average annual wage. Moreover, the results include year-by-job loss, number of childrenby-job loss, and state-by-job loss fixed effects, as well as state-specific linear time trends, and are weighted using the SIPP provided sample weights. Standard errors are clustered by state and shown in parentheses. $* \mathrm{p}<0.10, * * \mathrm{p}<0.05, * * * \mathrm{p}<0.01$.

Table A.2: Effect of UI Generosity on Risky Behaviors - BRFSS

\begin{tabular}{|c|c|c|c|c|c|c|c|}
\hline & \multicolumn{2}{|c|}{ BMI } & \multicolumn{2}{|c|}{ Smoking } & \multicolumn{2}{|c|}{ N. Days Drinking } & \multirow{2}{*}{$\begin{array}{c}\text { Pregnant } \\
\text { Now } \\
\end{array}$} \\
\hline & High $(>25)$ & Normal (18-25) & Sometimes & Daily & Any & At Least 5 & \\
\hline \multicolumn{8}{|c|}{ A: State, Year Fixed Effects: Unemployed } \\
\hline R-rate & $\begin{array}{c}-0.128^{*} \\
(0.070)\end{array}$ & $\begin{array}{c}0.161^{*} \\
(0.086)\end{array}$ & $\begin{array}{c}0.124 \\
(0.083)\end{array}$ & $\begin{array}{c}0.051 \\
(0.085)\end{array}$ & $\begin{array}{l}-1.816 \\
(2.150)\end{array}$ & $\begin{array}{c}1.662 \\
(1.259)\end{array}$ & $\begin{array}{l}-0.012 \\
(0.051)\end{array}$ \\
\hline Mean Y & 0.58 & 0.40 & 0.36 & 0.27 & 5.54 & 1.99 & 0.07 \\
\hline Observations & 138279 & 138279 & 143454 & 143454 & 102455 & 70010 & 47739 \\
\hline \multicolumn{8}{|c|}{ B: Triple Differences, State* Year*Kids FEs } \\
\hline R-rate * Unemployed & $\begin{array}{l}-0.049 \\
(0.056)\end{array}$ & $\begin{array}{c}0.086 \\
(0.078)\end{array}$ & $\begin{array}{c}0.054 \\
(0.086)\end{array}$ & $\begin{array}{c}0.072 \\
(0.046)\end{array}$ & $\begin{array}{l}-2.435 \\
(1.813)\end{array}$ & $\begin{array}{c}1.665^{* * *} \\
(0.619)\end{array}$ & $\begin{array}{c}-0.097 \\
(0.084)\end{array}$ \\
\hline Mean Y & 0.60 & 0.39 & 0.24 & 0.18 & 6.03 & 1.32 & 0.04 \\
\hline Observations & 2698627 & 2698627 & 2799285 & 2799285 & 2018944 & 1520878 & 830688 \\
\hline
\end{tabular}

Notes: Data are from the 1993-2015 Behavioral Risk Factor Surveillance System (BRFSS). The sample includes individuals who have been unemployed for less than a year or who are currently working for wages. I exclude individuals with missing demographics and those older than 60. All regressions include flexible demographic controls, as well as cubic polynomials for the state unemployment rate and the state average annual wage. Moreover, the results in Panel A include year and state fixed effects and state-specific linear time trends, while the regressions in Panel B include state-by-job loss, year-by-job loss, children-by-job loss, and state-by-year-by-number of children fixed effects. The results are weighted using the BRFSS provided sample weights. Standard errors are clustered by state and shown in parentheses. ${ }^{*} \mathrm{p}<0.10,{ }^{* *} \mathrm{p}<0.05,{ }^{* * *} \mathrm{p}<0.01$. 
Table A.3: Heterogeneity of Effects by Demographics - BRFSS

\begin{tabular}{|c|c|c|c|c|c|c|}
\hline & $(1)$ & $(2)$ & $(3)$ & $(4)$ & $(5)$ & $(6)$ \\
\hline \multicolumn{7}{|l|}{ A: Insurance Coverage } \\
\hline$\overline{\text { R-rate }}$ & $\begin{array}{c}0.327^{* *} \\
(0.123)\end{array}$ & $\begin{array}{c}0.233^{*} \\
(0.123)\end{array}$ & $\begin{array}{l}0.307^{* *} \\
(0.145)\end{array}$ & $\begin{array}{c}0.408^{* * *} \\
(0.129)\end{array}$ & $\begin{array}{l}0.317^{* *} \\
(0.122)\end{array}$ & $\begin{array}{l}-0.209 \\
(0.137)\end{array}$ \\
\hline R-rate $*$ Female & & $\begin{array}{c}0.185 \\
(0.114)\end{array}$ & & & & \\
\hline R-rate $*$ Married & & & $\begin{array}{c}0.046 \\
(0.108)\end{array}$ & & & \\
\hline R-rate $*$ College & & & & $\begin{array}{c}-0.495^{* * *} \\
(0.091)\end{array}$ & & \\
\hline R-rate $*$ No Children & & & & & $\begin{array}{c}0.064 \\
(0.072)\end{array}$ & \\
\hline R-rate * Generous Mec & licaid & & & & & $\begin{array}{c}0.666^{* * *} \\
(0.160)\end{array}$ \\
\hline \multicolumn{7}{|l|}{ B: Check-up } \\
\hline$\overline{\text { R-rate }}$ & $\begin{array}{c}0.344^{* * *} \\
(0.104)\end{array}$ & $\begin{array}{l}0.356^{* *} \\
(0.163)\end{array}$ & $\begin{array}{c}0.370^{* * *} \\
(0.120)\end{array}$ & $\begin{array}{c}0.381^{\text {*** }} \\
(0.107)\end{array}$ & $\begin{array}{c}0.311^{\text {*** }} \\
(0.092)\end{array}$ & $\begin{array}{l}-0.047 \\
(0.171)\end{array}$ \\
\hline R-rate ${ }^{*}$ Female & & $\begin{array}{c}-0.024 \\
(0.149)\end{array}$ & & & & \\
\hline R-rate $*$ Married & & & $\begin{array}{c}-0.059 \\
(0.110)\end{array}$ & & & \\
\hline R-rate $*$ College & & & & $\begin{array}{c}-0.229^{* *} \\
(0.104)\end{array}$ & & \\
\hline R-rate $*$ No Children & & & & & $\begin{array}{c}0.260^{* * *} \\
(0.091)\end{array}$ & \\
\hline R-rate $*$ Generous Mec & licaid & & & & & $0.476^{* *}$ \\
\hline \multicolumn{7}{|c|}{ C: General Health Status } \\
\hline R-rate & $\begin{array}{c}0.237 \\
(0.185)\end{array}$ & $\begin{array}{c}0.282^{*} \\
(0.163)\end{array}$ & $\begin{array}{c}0.231 \\
(0.159)\end{array}$ & $\begin{array}{c}0.216 \\
(0.179)\end{array}$ & $\begin{array}{c}0.220 \\
(0.194)\end{array}$ & $\begin{array}{l}0.815^{* *} \\
(0.382)\end{array}$ \\
\hline R-rate $*$ Female & & $\begin{array}{c}-0.088 \\
(0.154)\end{array}$ & & & & \\
\hline R-rate ${ }^{*}$ Married & & & $\begin{array}{c}0.014 \\
(0.243)\end{array}$ & & & \\
\hline R-rate $*$ College & & & & $\begin{array}{c}0.132 \\
(0.228)\end{array}$ & & \\
\hline R-rate $*$ No Children & & & & & $\begin{array}{c}0.118 \\
(0.121)\end{array}$ & \\
\hline R-rate * Generous Mec & licaid & & & & & $\begin{array}{l}-0.718^{*} \\
(0.379) \\
\end{array}$ \\
\hline
\end{tabular}

Notes: Data are from the 1993-2015 Behavioral Risk Factor Surveillance System (BRFSS). The sample includes individuals who have been unemployed for less than a year or who are currently working for wages. I exclude individuals with missing demographics and those older than 60. All regressions include flexible demographic controls, cubic polynomials for the state unemployment rate and the state average annual wage, as well as year and state fixed effects and state-specific linear time trends. The results are weighted using the BRFSS provided sample weights. Standard errors are clustered by state and shown in parentheses. ${ }^{*} \mathrm{p}<0.10,{ }^{* *} \mathrm{p}<0.05,{ }^{* * *} \mathrm{p}<0.01$. 


\section{B Data Appendix}

In this section, I first describe how I create the UI calculator that assigns weekly benefit amounts to unemployed individuals. Then I describe how I compute the simulated replacement rates that I use as the measure of UI generosity throughout the paper. Last, I describe all the sources of data used in the various analyses contained in this paper.

\section{B.1 UI Laws and Calculator}

The Unemployment Insurance (UI) program is a federal-state joint program, financed by a mix of federal and state payroll taxes. While the federal government specifies broad guidelines, states set their own UI programs, leading to a lot of variety in eligibility criteria, benefit amounts and benefit duration across states. ${ }^{31}$ In general, both eligibility and benefit amounts depend on individuals' work history prior to (involuntary) job loss, and in some states also on their number of dependents. ${ }^{32}$

To determine eligibility for the UI program, a state examines an individual's earnings and/or hours/weeks of employment during the "base period", which most states define as the first 4 of the last 5 completed calendar quarters of earnings prior to job loss. ${ }^{33}$ There are several methods that states use to determine eligibility for benefits, in order of occurrence:

1. Multiple of High-Quarter Wage - Individuals must earn a certain minimum in the quarter with the highest earnings of their base period. Moreover, their earnings in the base year must be a multiple of their highest earnings quarter (ie. 1.5).

2. Multiple of Weekly Benefit Amount - After computing individuals weekly benefit amount (WBA), states confer UI eligibility only if their earnings in the base period are greater than a multiple of the WBA (ie. 40). States may also require positive earnings in multiple quarters of the base period.

3. Flat Qualifying Amount - Individuals must have earned a minimum amount in the base period.

4. Weeks/Hours of Employment - Individuals must have worked a minimum amount of hours/weeks at a certain weekly/hourly wage in the base period.

\footnotetext{
${ }^{31}$ In this paper I do not take advantage of the variation in duration of benefits, hence I will ignore duration of benefits for the remainder of this appendix.

${ }^{32}$ For more information, see https://workforcesecurity.doleta.gov/unemploy/comparison2017.asp. Rules explained in this Appendix are as of January 1st, 2017.

${ }^{33} \mathrm{As}$ of 2017, exceptions to this standard are Massachusetts and Minnesota, which use the last 4 quarters. Moreover, some states use alternative base periods (ABPs) or Extended Base Periods (EBPs) to confer eligibility to some individuals that are attached to the labor market but might not quality according to their work history in the base year. For this project, I do not use any rules on ABP and EBP earnings to assign UI eligibility.
} 
States also follow different methods for determining the weekly benefit amount an individual receives, with the $\mathrm{WBA}$ equal to:

1. High-Quarter Method - A percent of total earnings in the highest quarter of the base year (ie. 1/26). This is the most popular method.

2. Multi-Quarter Method - A percent of total (or average) earnings in multiple quarters in the base period.

3. Annual-Wage Method - A percent of annual wages in the base period.

4. Weekly-Wage Method - A percent of average weekly wages in the base period.

Moreover, states also have rules on minimum and maximum weekly benefits, which they use if an individual's WBA is below or above these thresholds. These thresholds vary considerably across states and years, with the minimum WBA varying from no minimum to \$151 between 1993-2015, and the maximum varying between $\$ 140$ and $\$ 798$. Furthermore, some states allow additional benefits for dependents, which vary between $\$ 1$ and $\$ 25$ per dependent, up to a maximum dependent allowance. Lastly, the American Recovery and Reinvestment Act (ARRA) of 2009 increased unemployment benefits by $\$ 25$ per week for all recipients, with some states providing temporary additional benefits on top of the federal increase.

To construct the UI calculator, I gathered information on these state laws for all years from 1993 to 2015 from a variety of sources. The main information was collected from the Employment and Training Administration (ETA), which reports semi-annual information on state benefit schedules. Moreover, I supplemented this data with information from the calculators used in Gruber (1997), Chetty (2008) and LaLumia (2013), as well as other state laws and documents whenever the ETA information was incomplete.

\section{B.2 Simulated Replacement Rates}

To create the simulated replacement rates, my measure of UI generosity, I start with a sample of newly unemployed individuals from the 1996, 2001, 2004, and 2008 panels of the Survey of Income and Program Participation (SIPP), which cover individuals interviewed in years 1996-2013. To create the sample, I perform the following sample restrictions. First, I identify individuals that are currently working or unemployed, and I restrict the sample to those who are unemployed at least once during the survey and who, prior to unemployment, were working for at least three months and had positive earnings. This restriction is needed to assure that we have information on at least one full quarter of earnings. After creating variables for quarterly earning for all quarters prior to the current one, ${ }^{34}$ I restrict the sample to individual who are newly unemployed, i.e. who

\footnotetext{
${ }^{34}$ Since the SIPP is a short longitudinal survey, following individuals for 2-4 years at most, I cannot always collect information on all 4 quarters of earnings prior to job loss. When this is the case, I assume earnings in the previous quarter are the same as earnings in the last quarter the individual is observed working. This assumption introduces some measurement error when calculating UI benefit eligibility.
} 
were employed in the previous month but are now unemployed. Last, I restrict the sample to individuals aged 18 to 60 , who are more likely to be attached to the labor market. ${ }^{35}$ After all these restrictions, the sample is comprised of 64,730 individuals.

Once I have this fixed, national sample of individuals, I calculate their weekly UI benefits according to each state-year set of laws. For example, I first assume all individuals in the sample lost their job in 1993 in Alabama, transform their earnings in 1993 values, calculate their federal taxes according to TAXSIM (Feenberg and Coutts, 1993), ${ }^{36}$ calculate their UI weekly benefits eligibility according to the law present in Alabama in January of 1993, and then divide these benefits by the individual's weekly earnings to obtain their simulated replacement rate. Then I re-start the calculator assuming the individual lost their job in 1993 in Alaska, and so forth and so on for all state and year combinations. Finally, I collapse the data to the year, state and number of children cell to capture the average simulated replacement rates in each of these cells. The simulated replacement rates I obtained from this exercise are plotted in Figure B.1.

\section{B.3 Data Sources}

State employment and unemployment: Bureau of Labor Statistics (BLS), 1993-2015

State population: National Cancer Institute SEER; 1993-2015

State average weekly earnings: March Supplement of the Current Population Survey (CPS); 19942016

State UI benefits paid and reserves: Department of Labor Employment Training Administration (ETA) and Hsu, Matsa and Melzer (2018); 1993-2015

State spending on SNAP, AFDC/TANF, Medicaid, EITC, and SS: Bureau of Economic Analysis (BEA) Regional Economic Accounts; 1993-2015

State EITC parameters: Tax Policy Center; 1993-2015

Maximum AFDC/TANF benefits and minimum wages: University of Kentucky Center for Poverty Research (UKCPR); 1993-2015

State welfare reform: Bitler and Hoynes (2010); 1993-2015

State Medicaid/SCHIP income eligibility thresholds (for children and pregnant women): Hoynes and Luttmer (2011), the Maternal and Child Health Update from National Governor's Association and the Kaiser Family Foundation Annual Updates; 1993-2014

State-by-number of children employment, unemployment, and population: Current Population Survey (CPS); 1993-2015

\footnotetext{
${ }^{35}$ I also exclude from the sample individuals whose birth year from interview to interview was different by more than one year, around 1 percent of the sample, as these may not be the same individuals.

${ }^{36}$ Prior to 2002, Michigan's WBA formula depended on an individuals' average tax rate.
} 
Figure B.1: Average Simulated Replacement Rates
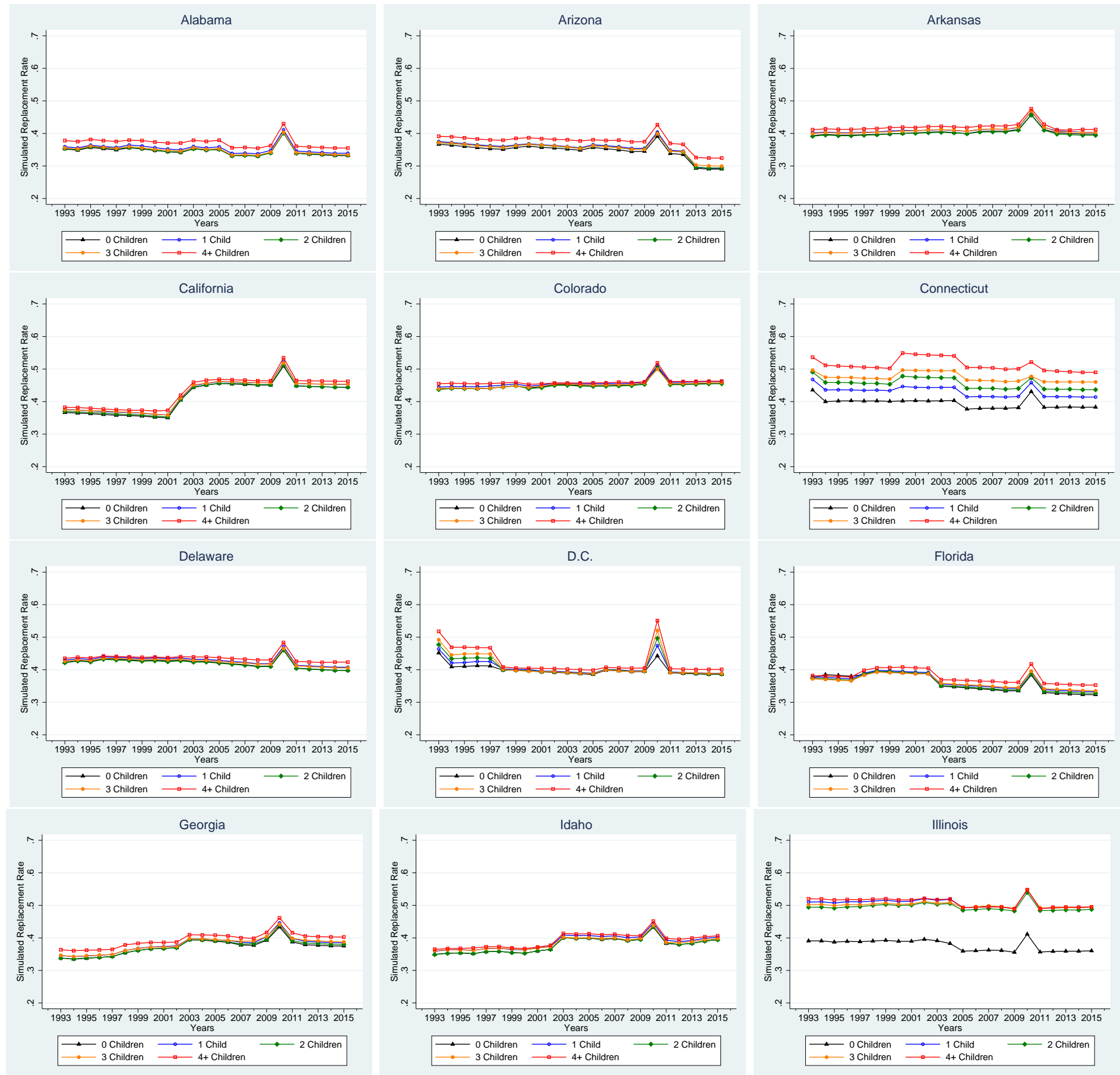


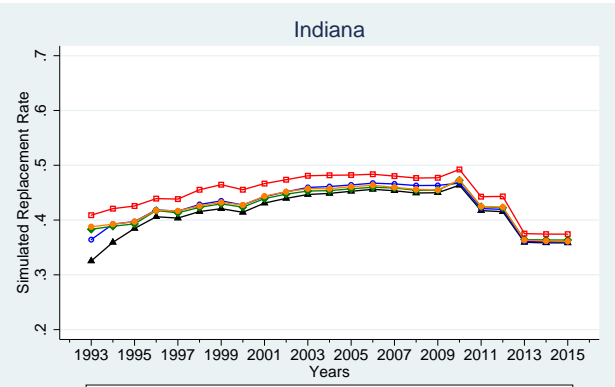

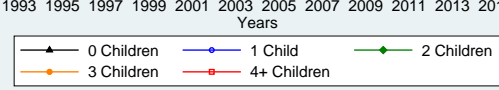

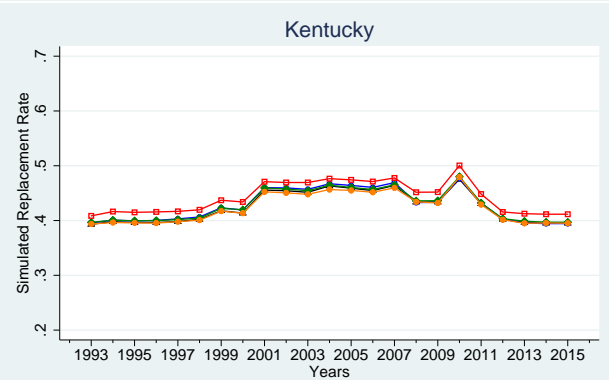

$1993 \quad 19951997199920012003200520072009201120132015$

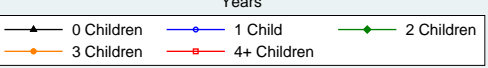

Maryland
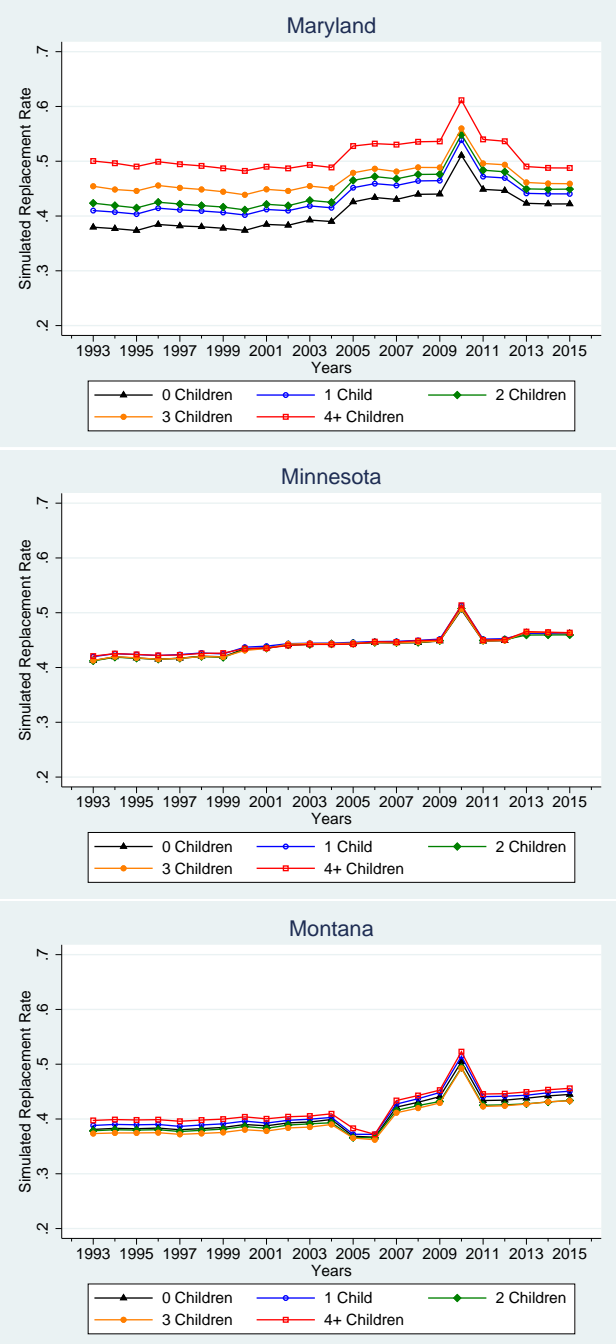

lowa

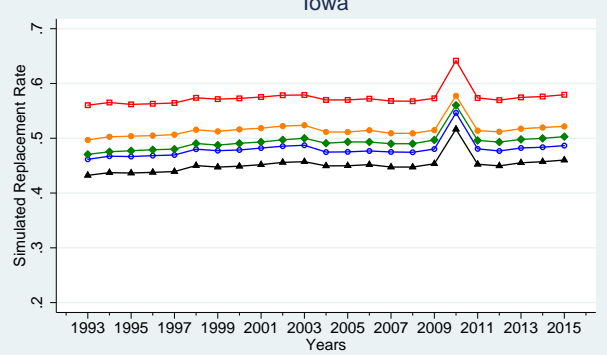

Years
$\longrightarrow-0$ Children $\longrightarrow 1$ Child $\longrightarrow 2$ Children

Louisiana
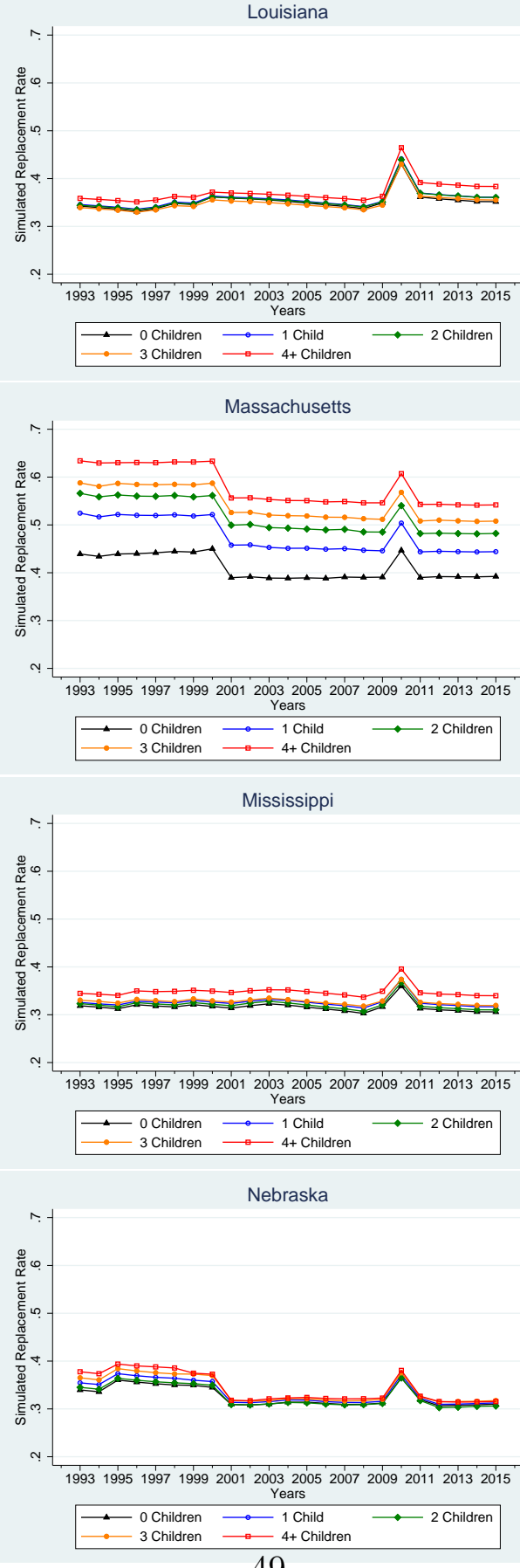

Kansas

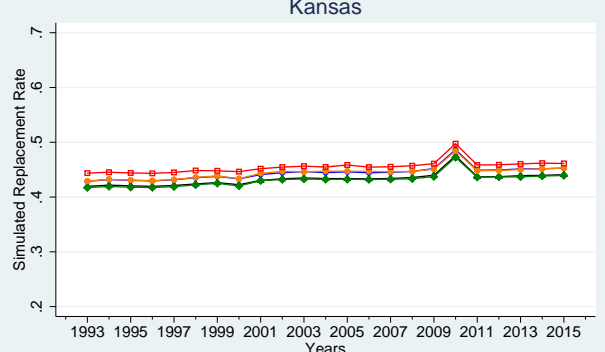

Years
$\longrightarrow$ — 0 Children $\longrightarrow$ Child $\longrightarrow 2$ Children

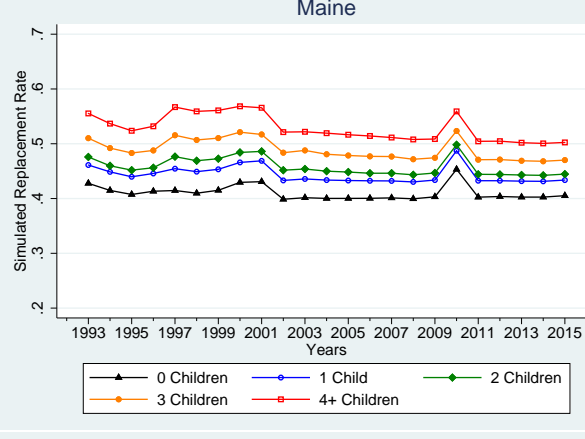

Michigan

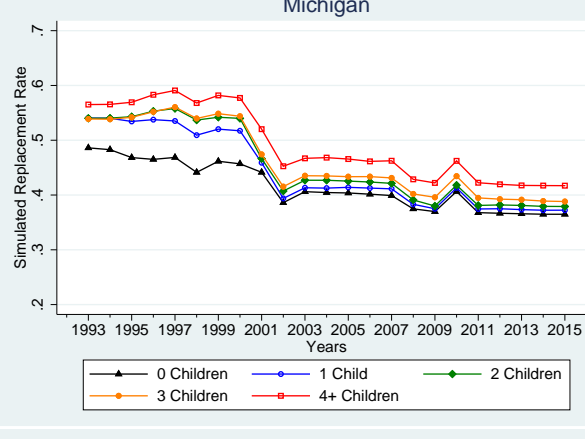

Missouri

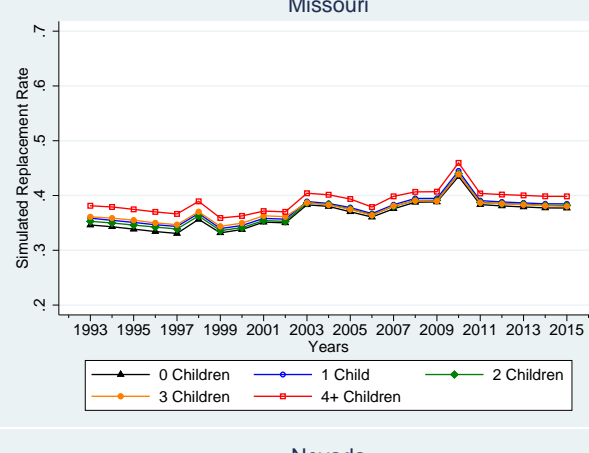

Nevada

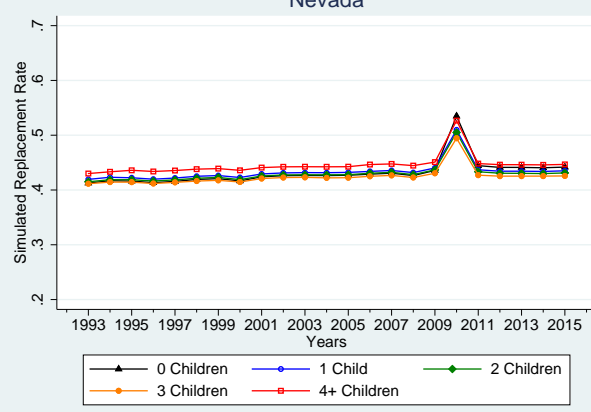




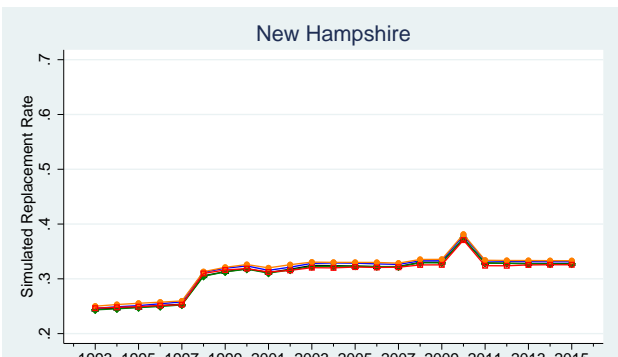

199319951997199920012003200520072009201120132015

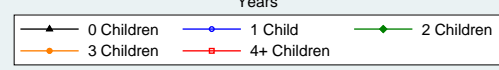

New York

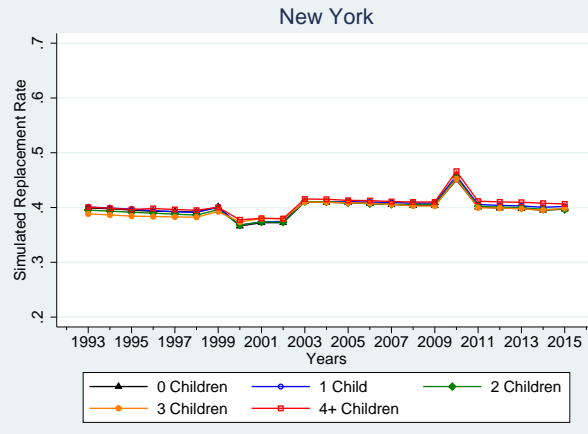

Ohio
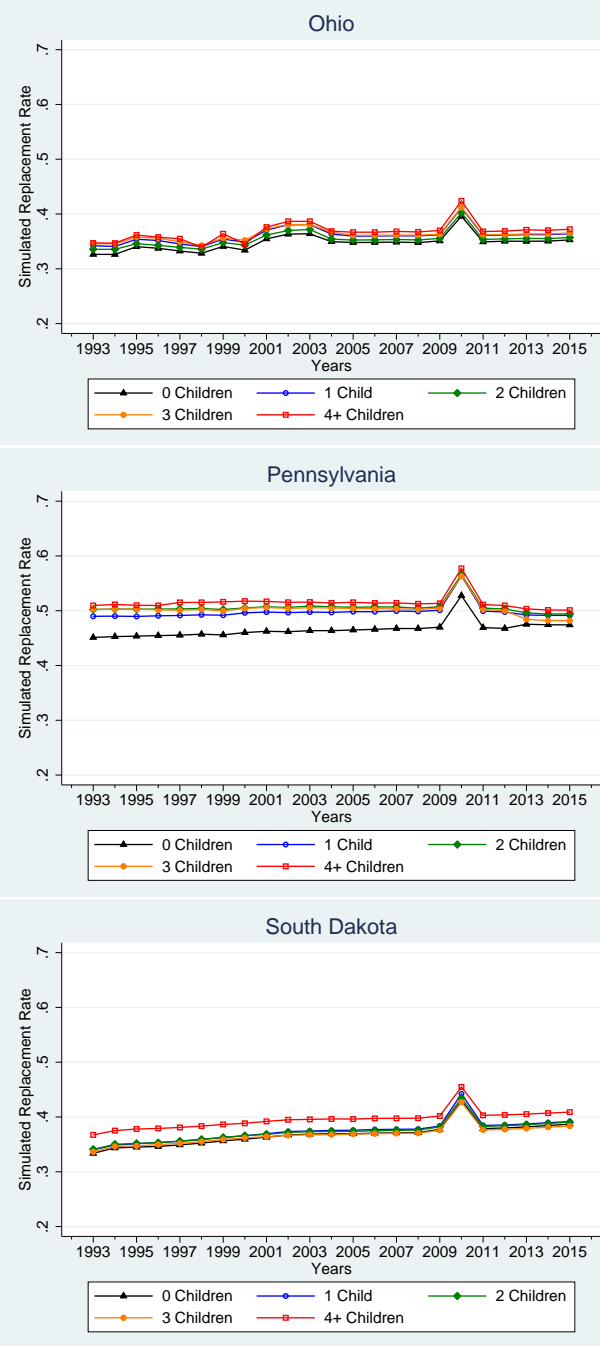

New Jersey
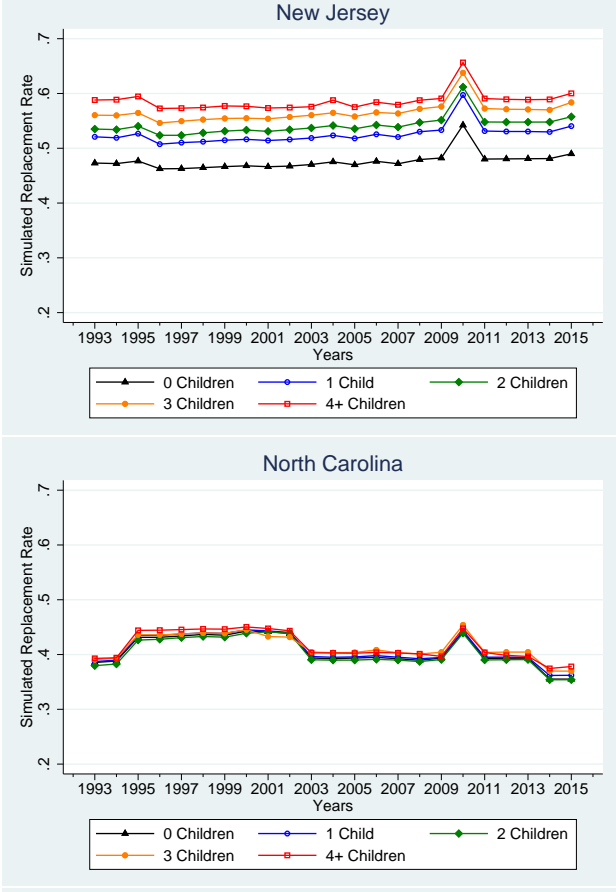

Oklahoma
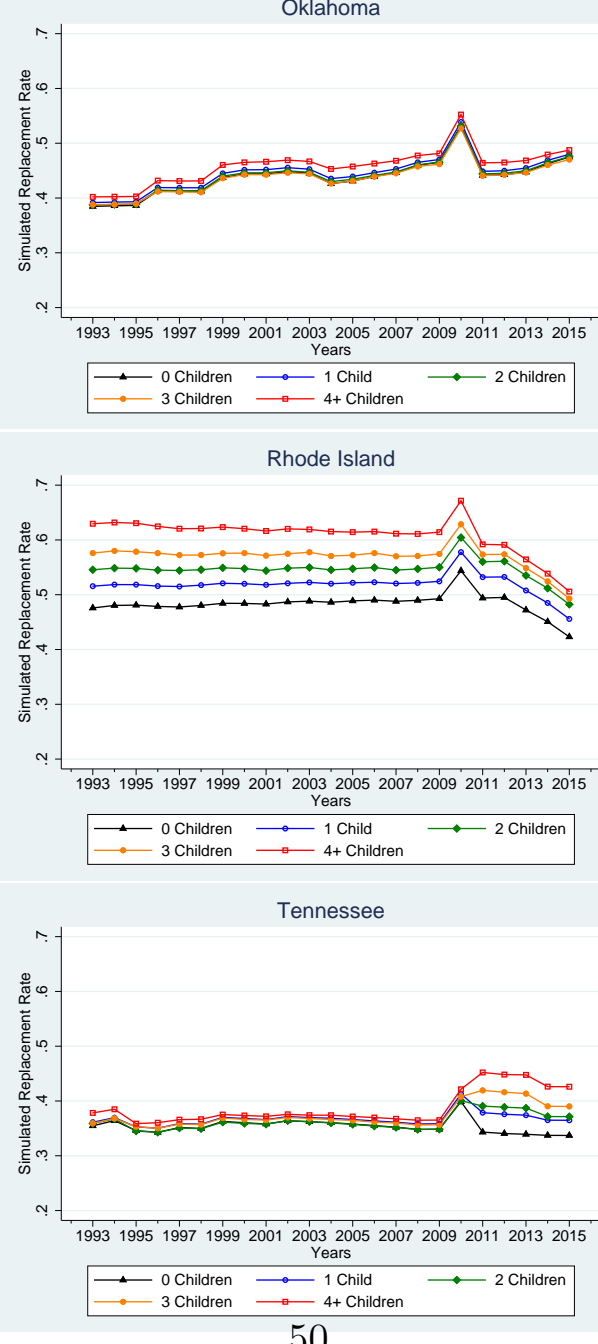

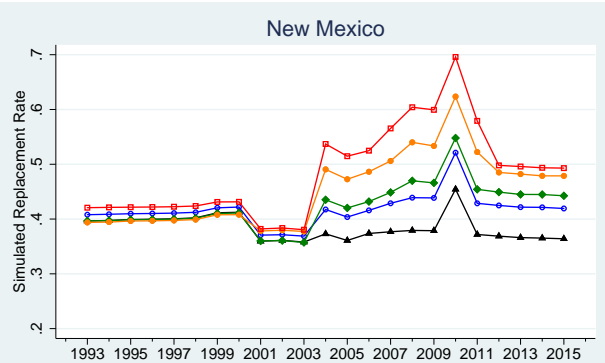

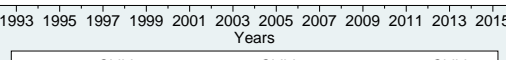

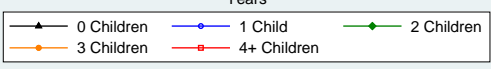

North Dakota

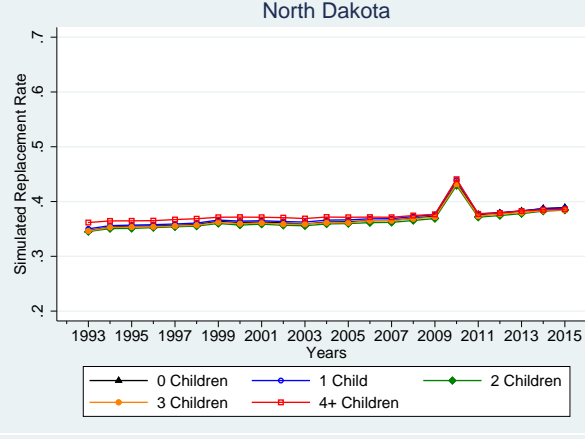

Oregon

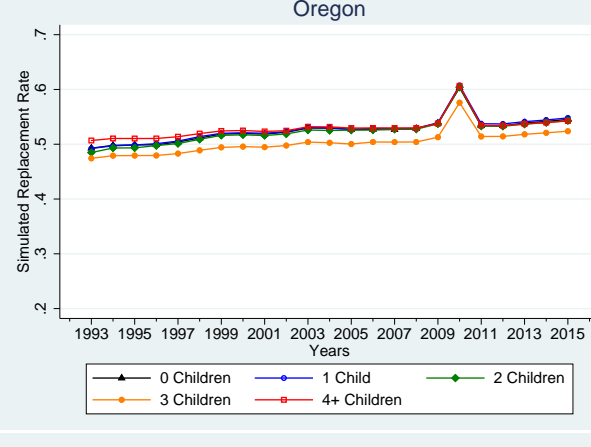

South Carolina
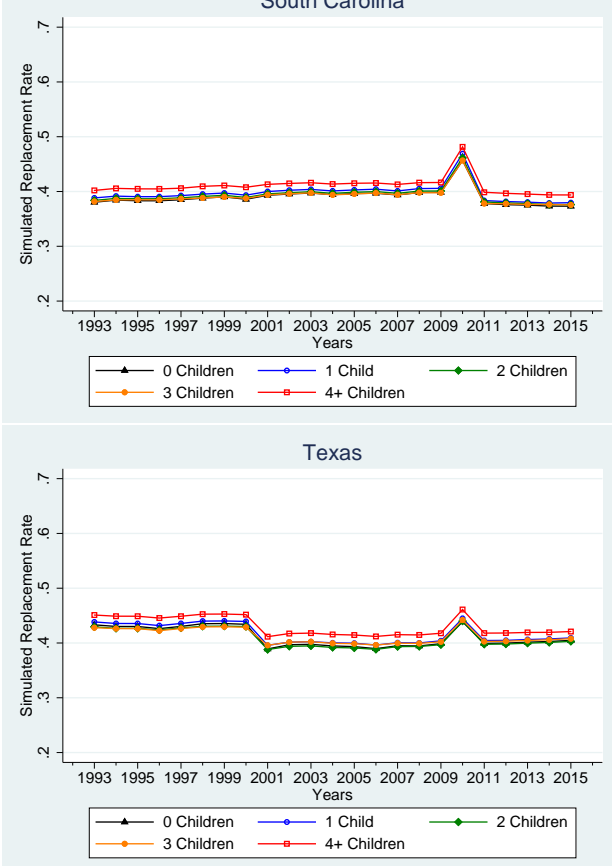

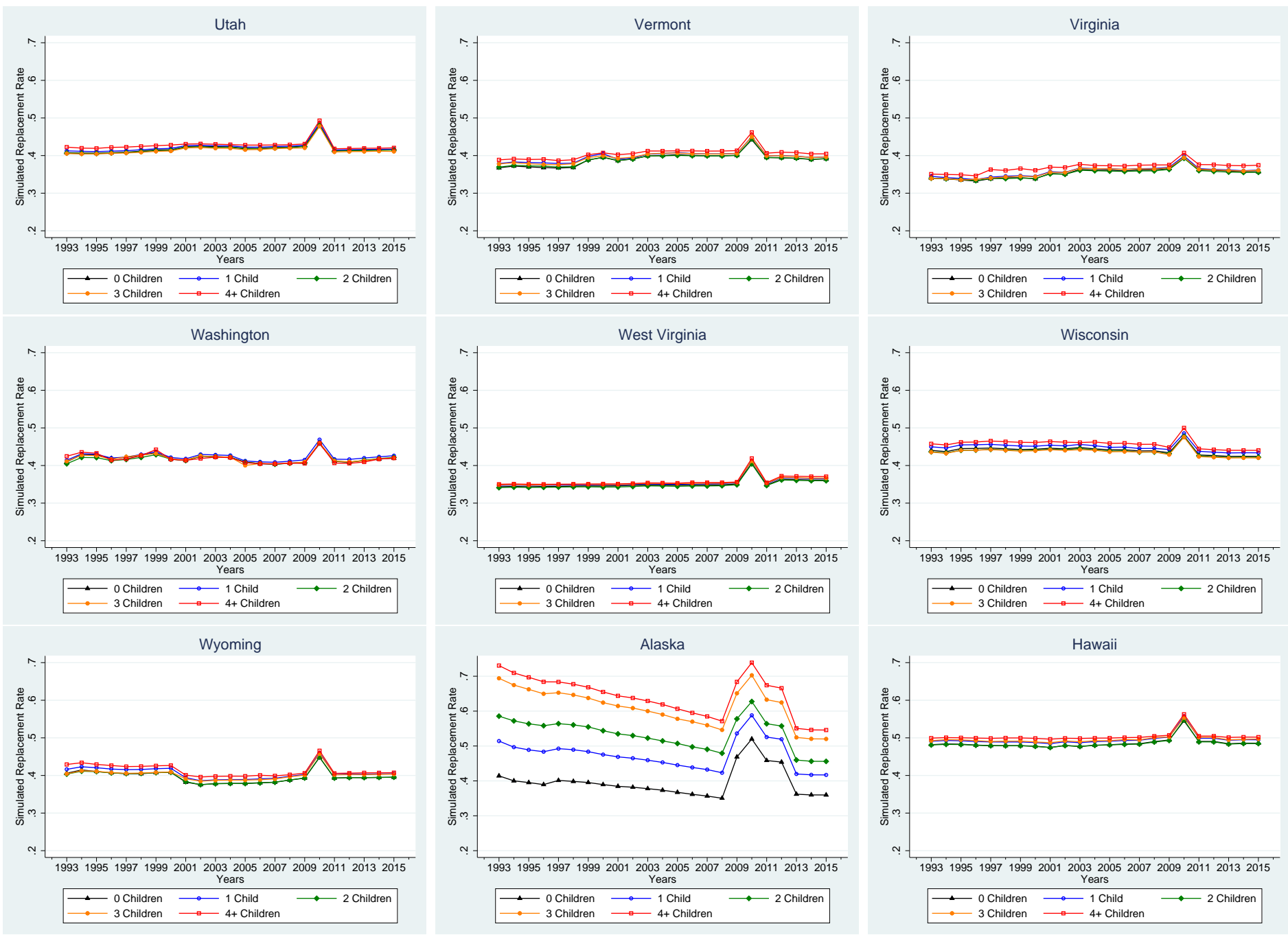

Notes: Data are from the 1996-2008 panels of the Survey of Income and Program Participation (SIPP). The sample includes all individuals that experience an unemployment spell, at the start of their spell. I then run this simulated sample through the UI generosity calculator, and then collapse the sample to have an average simulated replacement rate for each state, year and number of children. 


\section{Additional Tests for Exogeneity of UI}

One of the major identification assumptions in my analysis is that changes in UI generosity are not correlated other factors that also affect health status and utilization. For example, one could be worried that legislators change UI generosity when they observe worsening economic conditions. Table (2) showed no evidence of this possible threat to identification, as UI generosity is not correlated to state unemployment rates, average earnings, and employment rates. In this section, I probe further into this question.

Given that states are believed to change UI benefits when state UI funds are low (Smith and Wenger, 2013), which usually occurs immediately after periods of high unemployment rates, in Table (C.1) I test whether lagged unemployment rates and net UI reserves are correlated with current UI generosity. These results suggest that the unemployment rate and net UI reserves in the previous year are the variables more significantly correlated with UI generosity, providing some empirical evidence that states do indeed decrease UI benefits after periods of bad economic conditions, when UI funds are likely depleted.

While one may be worried that states change UI during recessions, which are correlated with improved health, the results in Table (C.1) suggest that UI generosity decreases after periods of high unemployment rates, weakening this worry. Nevertheless, it is important to fully and flexibly control for both current and lagged economic conditions. Therefore, all my baseline specifications contains flexible control for current conditions, and in robustness checks I showed that the main results are not sensitive to also including flexible controls for lagged conditions, suggesting that past economic conditions are not also correlated with the health of currently unemployed individuals. Moreover, note that in the triple difference BRFSS specification that includes state-by-year-by-number of children fixed effects, these fixed effects absorb all (observed and unobserved) state-by-year variation, including state economic conditions.

Lastly, in Section 4.4 I discussed how contemporaneous changes in other safety net programs could lead to biased estimates of UI, and I used state-year level observations to show that state UI generosity is not significantly correlated to changes in other programs' generosity nor spending per capita. However, one might argue that these tests are not computed at the right level of aggregation, as the measure of UI generosity varies also across number of children. Hence, I use information from the 1993-2015 CPS and the 1996-2013 SIPP datasets to construct average state economic conditions and program spending at the stateyear-number of children level, and I repeat the analyses above with these data. Appendix Tables (C.2) and (C.3) show similar results to the ones discussed above, at the state-year level only. 
Table C.1: Effect of State Lagged Economics Conditions on UI Generosity

\begin{tabular}{|c|c|c|c|c|c|}
\hline & $(1)$ & $(2)$ & $(3)$ & $(4)$ & $(5)$ \\
\hline 1 Lag Unemployment Rate (\%) & $\begin{array}{l}-2.604^{*} \\
(1.330)\end{array}$ & $\begin{array}{l}-2.116 \\
(1.571)\end{array}$ & & & $\begin{array}{l}-2.137 \\
(1.373)\end{array}$ \\
\hline 1 Lag Unemployment Rate ${ }^{2}$ & $\begin{array}{c}0.289^{*} \\
(0.151)\end{array}$ & $\begin{array}{c}0.295 \\
(0.193)\end{array}$ & & & $\begin{array}{c}0.263 \\
(0.171)\end{array}$ \\
\hline 1 Lag Unemployment Rate ${ }^{3}$ & $\begin{array}{c}-0.011^{*} \\
(0.006)\end{array}$ & $\begin{array}{l}-0.012 \\
(0.007)\end{array}$ & & & $\begin{array}{l}-0.010 \\
(0.007)\end{array}$ \\
\hline 2 Lag Unemployment Rate (\%) & & $\begin{array}{l}-0.616 \\
(0.935)\end{array}$ & & & $\begin{array}{l}-0.400 \\
(0.885)\end{array}$ \\
\hline 2 Lag Unemployment Rate ${ }^{2}$ & & $\begin{array}{c}-0.008 \\
(0.113)\end{array}$ & & & $\begin{array}{c}-0.063 \\
(0.119)\end{array}$ \\
\hline 2 Lag Unemployment Rate ${ }^{3}$ & & $\begin{array}{c}0.001 \\
(0.004)\end{array}$ & & & $\begin{array}{c}0.006 \\
(0.005)\end{array}$ \\
\hline 1 Lag (UI Net Reserves/Population) (\%) & & & $\begin{array}{c}0.040^{* * *} \\
(0.014)\end{array}$ & $\begin{array}{l}-0.028 \\
(0.044)\end{array}$ & $\begin{array}{l}-0.030 \\
(0.036)\end{array}$ \\
\hline 1 Lag (UI Net Reserves/Population) ${ }^{2}$ & & & $\begin{array}{c}-0.001^{* *} \\
(0.001)\end{array}$ & $\begin{array}{c}-0.001^{*} \\
(0.001)\end{array}$ & $\begin{array}{r}-0.002^{* *} \\
(0.001)\end{array}$ \\
\hline 1 Lag (UI Net Reserves/Population) ${ }^{3}$ & & & $\begin{array}{c}0.000 \\
(0.000)\end{array}$ & $\begin{array}{c}0.000 \\
(0.000)\end{array}$ & $\begin{array}{c}0.000 \\
(0.000)\end{array}$ \\
\hline 2 Lag (UI Net Reserves/Population) (\%) & & & & $\begin{array}{c}0.083 \\
(0.052)\end{array}$ & $\begin{array}{c}0.068^{*} \\
(0.040)\end{array}$ \\
\hline 2 Lag (UI Net Reserves/Population) ${ }^{2}$ & & & & $\begin{array}{c}-0.000 \\
(0.000)\end{array}$ & $\begin{array}{l}-0.001 \\
(0.001)\end{array}$ \\
\hline 2 Lag (UI Net Reserves/Population) ${ }^{3}$ & & & & $\begin{array}{l}-0.000 \\
(0.000)\end{array}$ & $\begin{array}{c}0.000 \\
(0.000)\end{array}$ \\
\hline Unemployment Rate (\%) & & & & & $\begin{array}{c}0.010 \\
(0.175)\end{array}$ \\
\hline Average Weekly Wage $(\$ 2015,1000$ s) & & & & & $\begin{array}{l}-0.779 \\
(2.952)\end{array}$ \\
\hline R-squared & 0.928 & 0.931 & 0.930 & 0.933 & 0.938 \\
\hline Observations & 1173 & 1173 & 1173 & 1173 & 1173 \\
\hline
\end{tabular}

Notes: UI replacement rates are calculated using the 1996-2008 panels of the Survey of Income and Program Participation (SIPP). The state unemployment rate and employment level comes from the BLS, the state population is from SEER, average weekly wages are calculated with the CPS, and net reserves are from ETA. All regressions include state and year fixed effects, as well as state-specific linear time trends. All statistics are weighted using state population. Standard errors are clustered by state and shown in parentheses. ${ }^{*} \mathrm{p}<0.10,{ }^{* *} \mathrm{p}<0.05,{ }^{* * *} \mathrm{p}<0.01$. 
Table C.2: Effect of State Economics Conditions on UI Generosity State-Year-Number of Children Observations

\begin{tabular}{|c|c|c|c|c|c|c|c|c|}
\hline Unemployment Rate (\%) & $\begin{array}{l}-0.065 \\
(0.081)\end{array}$ & $\begin{array}{l}-0.404 \\
(0.273)\end{array}$ & & & & & & $\begin{array}{l}-0.242 \\
(0.225)\end{array}$ \\
\hline Unemployment Rate ${ }^{2}$ & & $\begin{array}{c}0.027 \\
(0.022)\end{array}$ & & & & & & $\begin{array}{c}0.025 \\
(0.020)\end{array}$ \\
\hline Unemployment Rate ${ }^{3}$ & & $\begin{array}{l}-0.001 \\
(0.001)\end{array}$ & & & & & & $\begin{array}{l}-0.001 \\
(0.001)\end{array}$ \\
\hline Employment/Population & & & $\begin{array}{c}10.275 \\
(12.472)\end{array}$ & & & & & \\
\hline Employment/Population ${ }^{2}$ & & & $\begin{array}{l}-0.126 \\
(0.144)\end{array}$ & & & & & \\
\hline Employment/Population ${ }^{3}$ & & & $\begin{array}{c}0.001 \\
(0.001)\end{array}$ & & & & & \\
\hline 1 Lag Unemployment Rate (\%) & & & & $\begin{array}{c}-0.640^{* *} \\
(0.249)\end{array}$ & $\begin{array}{c}-0.392 \\
(0.260)\end{array}$ & & & $\begin{array}{c}-0.587^{* *} \\
(0.286)\end{array}$ \\
\hline 1 Lag Unemployment Rate ${ }^{2}$ & & & & $\begin{array}{l}0.040^{* *} \\
(0.019)\end{array}$ & $\begin{array}{c}0.030 \\
(0.023)\end{array}$ & & & $\begin{array}{c}0.049^{*} \\
(0.026)\end{array}$ \\
\hline 1 Lag Unemployment Rate ${ }^{3}$ & & & & $\begin{array}{c}-0.001^{*} \\
(0.000)\end{array}$ & $\begin{array}{l}-0.001 \\
(0.001)\end{array}$ & & & $\begin{array}{c}-0.001^{*} \\
(0.001)\end{array}$ \\
\hline 2 Lag Unemployment Rate (\%) & & & & & $\begin{array}{c}-0.486^{*} \\
(0.250)\end{array}$ & & & $\begin{array}{c}-0.469^{* *} \\
(0.223)\end{array}$ \\
\hline 2 Lag Unemployment Rate ${ }^{2}$ & & & & & $\begin{array}{c}0.021 \\
(0.028)\end{array}$ & & & $\begin{array}{c}0.022 \\
(0.022)\end{array}$ \\
\hline 2 Lag Unemployment Rate ${ }^{3}$ & & & & & $\begin{array}{l}-0.000 \\
(0.001)\end{array}$ & & & $\begin{array}{l}-0.000 \\
(0.001)\end{array}$ \\
\hline 1 Lag (UI Net Reserves/GSP) (\%) & & & & & & $\begin{array}{c}0.016 \\
(0.012)\end{array}$ & $\begin{array}{c}0.010 \\
(0.025)\end{array}$ & $\begin{array}{c}0.006 \\
(0.023)\end{array}$ \\
\hline 1 Lag (UI Net Reserves/GSP) ${ }^{2}$ & & & & & & $\begin{array}{c}-0.001^{* * *} \\
(0.000)\end{array}$ & $\begin{array}{c}-0.001^{* *} \\
(0.000)\end{array}$ & $\begin{array}{c}-0.001^{* *} \\
(0.000)\end{array}$ \\
\hline 1 Lag (UI Net Reserves/GSP) ${ }^{3}$ & & & & & & $\begin{array}{c}0.000^{*} \\
(0.000)\end{array}$ & $\begin{array}{c}0.000 \\
(0.000)\end{array}$ & $\begin{array}{c}0.000^{*} \\
(0.000)\end{array}$ \\
\hline 2 Lag (UI Net Reserves/GSP) (\%) & & & & & & & $\begin{array}{c}0.007 \\
(0.023)\end{array}$ & $\begin{array}{c}0.001 \\
(0.021)\end{array}$ \\
\hline 2 Lag (UI Net Reserves/GSP) ${ }^{2}$ & & & & & & & $\begin{array}{l}-0.000 \\
(0.000)\end{array}$ & $\begin{array}{c}-0.000 \\
(0.000)\end{array}$ \\
\hline 2 Lag (UI Net Reserves/GSP) ${ }^{3}$ & & & & & & & $\begin{array}{c}0.000 \\
(0.000)\end{array}$ & $\begin{array}{c}0.000 \\
(0.000)\end{array}$ \\
\hline Mean R-rate & 41.00 & 41.00 & 41.00 & 41.00 & 41.00 & 41.01 & 41.01 & 41.01 \\
\hline R-Squared & 0.842 & 0.842 & 0.842 & 0.843 & 0.844 & 0.845 & 0.845 & 0.848 \\
\hline Observations & 5865 & 5865 & 5865 & 5865 & 5865 & 5814 & 5763 & 5763 \\
\hline
\end{tabular}

Notes: UI replacement rates are calculated using the 1996-2008 panels of the Survey of Income and Program Participation (SIPP). The state unemployment rate, employment level and population comes from the CPS, and net reserves are from ETA. All regressions include state, year and number of children fixed effects, as well as state-specific linear time trends. All statistics are weighted using cell population from the CPS. Standard errors are clustered by state and shown in parentheses. ${ }^{*} \mathrm{p}<0.10,{ }^{* *} \mathrm{p}<0.05,{ }^{* * *} \mathrm{p}<0.01$. 
Table C.3: Effect of UI Generosity on Safety Net Spending

\begin{tabular}{|c|c|c|c|c|c|}
\hline & SNAP & ADFC & SSI & SS & $\overline{\mathrm{UI}}$ \\
\hline \multicolumn{6}{|l|}{ A: CPS Data } \\
\hline R-rate & $\begin{array}{c}-3.114 \\
(19.265)\end{array}$ & $\begin{array}{c}4.207 \\
(9.009)\end{array}$ & $\begin{array}{c}66.983 \\
(78.713)\end{array}$ & $\begin{array}{l}-173.842 \\
(541.643)\end{array}$ & $\begin{array}{c}-94.040 \\
(63.853)\end{array}$ \\
\hline Mean Y & 20.63 & 8.20 & 50.90 & 841.91 & 48.58 \\
\hline Observations & 5865 & 5865 & 5865 & 5865 & 5865 \\
\hline \multicolumn{6}{|l|}{ B: SIPP Data } \\
\hline R-rate & $\begin{array}{c}1.224 \\
(28.895)\end{array}$ & $\begin{array}{c}6.431 \\
(9.511)\end{array}$ & $\begin{array}{c}69.673 \\
(94.897)\end{array}$ & $\begin{array}{l}-227.999 \\
(653.723)\end{array}$ & $\begin{array}{l}-90.855 \\
(70.557)\end{array}$ \\
\hline Mean Y & 23.85 & 7.83 & 53.77 & 731.98 & 41.17 \\
\hline Observations & 5033 & 5033 & 5033 & 5033 & 5033 \\
\hline
\end{tabular}

Notes: UI replacement rates are calculated using the 1996-2008 panels of the Survey of Income and Program Participation (SIPP). Program spending at the year, state and number of children level is calculated with CPS and SIPP data. All regressions include cubic polynomials for the state unemployment rate and the state average annual wage, as well as state, year and number of children fixed effects and state-specific linear time trends. All statistics are weighted using cell population from the CPS/SIPP. Standard errors are clustered by state and shown in parentheses. ${ }^{*} \mathrm{p}<0.10,{ }^{* *} \mathrm{p}<0.05,{ }^{* * *} \mathrm{p}<0.01$. 